Article

\title{
From Coffee to Biodiesel-Deep Eutectic Solvents for Feedstock and Biodiesel Purification
}

\author{
Aleksandra Sander ${ }^{1, *(D)}$, Ana Petračić ${ }^{1}$, Jelena Parlov Vuković ${ }^{2}$ and Lana Husinec ${ }^{2}$ \\ 1 Faculty of Chemical Engineering and Technology, University of Zagreb, Marulićev trg 19, 10000 Zagreb, \\ Croatia; apetracic@fkit.hr \\ 2 INA-Industrija nafte d.d., Lovinčićeva bb, 10000 Zagreb, Croatia; Jelena.Parlov-Vukovic@ina.hr (J.P.V.); \\ Lana.Magic@ina.hr (L.H.) \\ * Correspondence: asander@fkit.hr
}

Received: 28 February 2020; Accepted: 17 April 2020; Published: 18 April 2020

\begin{abstract}
Over three billion cups of coffee are consumed daily, making waste coffee grounds readily available throughout the world. Containing approximately $10-15 \mathrm{wt} \%$ of oil, they have great potential for biodiesel production. The goal of this work was to produce high quality biodiesel from waste coffee grounds. One fresh and four different types of waste coffee grounds were collected. Oil was extracted by the Soxhlet method with $n$-hexane and then purified via extractive deacidification with a potassium carbonate-based deep eutectic solvent. Biodiesels were synthesized by means of alkali catalyzed transesterification at different catalyst:methanol:oil mass ratios and reaction times. Impurities present in crude biodiesels were extracted with a choline chloride-based deep eutectic solvent. All batch extraction experiments were performed at room conditions in a small scale extractor. Optimal conditions for synthesis and purification were defined in order to assure high quality of the produced biodiesel. Additionally, continuous column extraction with the choline chloride-based solvent was tested as a purification method for crude biodiesel. Stabilization time and optimal biodiesel to solvent mass ratio were determined. The potassium carbonate-based solvent efficiently reduced the total acid number of the feedstock (deacidification efficiency ranged from 86.18 to $94.15 \%$ ), while the one based on choline chloride removed free glycerol and glycerides from crude biodiesels. After continuous purification, the purified biodiesel was of excellent quality with glycerol and glyceride contents below the EN 14214 limit.
\end{abstract}

Keywords: biodiesel; deacidification; deep eutectic solvents; waste coffee grounds

\section{Introduction}

A Scopus search on the term "waste coffee grounds" (WCGs) uncovers an interesting trend. Since 2000, research interest has grown significantly, with 490 papers published on the topic, over half of them in the last four years and the trend is expected to continue in 2020. Papers have explore coffee and WCG chemical composition [1], availability and environmental implications [2], and their possible uses and processes required [3]. Being the second most traded commodity, coffee is present in every corner of the world. It is of vital importance to 25 million families growing it and over 70 countries exporting it to the world, retailers, roasters, and their employees in the supply chain as well as to millions of people who start their day with a cup of coffee [4]. With coffee being so widely consumed, waste coffee grounds make a readily available material for further utilization.

After brewing, waste coffee grounds contain on average 10-15 wt $\%$ of oil, depending on the type of coffee and the processing it went through [5]. Apart from lipids, WCGs also contain polysaccharides, proteins, nitrogenous non-protein compounds, minerals, and phenolic compounds. Nitrogenous compounds such as free amino acids, peptides, and alkaloids enable some interesting 
applications in agriculture. Having a favorable carbon to nitrogen ratio after oil extraction, WCGs can be used as compost in the garden [6]. Beker et al. explored the benefits of WCG biodiesel antimicrobial potential for use in diesel blend B10 [7].

Biodiesel is a mixture of fatty acid alkyl esters produced from triglycerides and alcohols in the presence of a catalyst via chemical transesterification. The most commonly used alcohol is methanol, and the most common triglyceride sources include palm oil, sunflower oil, rapeseed oil, etc. The number of papers on biodiesel shows a growing trend and the production of biodiesel from numerous feedstocks including waste animal fats, waste cooking oil, algae, and more is being investigated [8-13]. Due to strict European legislation regarding renewable energy sources, the focus of researchers is moving to waste and low quality feedstocks in order to avoid the negative environmental impacts of cultivating crops for energy production.

In the last 12 years, 89 papers explored the use of waste coffee grounds for biodiesel production. Methods for oil extraction were explored, for example, batch extraction with organic solvents such as methanol, ethanol, $n$-hexane, iso-propanol, etc. and Soxhlet extraction with the aforementioned solvents and their mixtures in different ratios $[3,14,15]$. The drying kinetics of wet WCGs was investigated in [16] and in situ transesterification has also been investigated, skipping the oil extraction process and synthesizing biodiesel directly from waste coffee grounds [17-21].

Since WCG oil often has a free fatty acid (FFA) content over 1\% FFA (which corresponds to the total acid number, TAN, of over $2 \mathrm{mg} \mathrm{KOH} / \mathrm{g}$ oil), biodiesel should not be produced via base catalyzed transesterification in order to avoid saponification. Therefore, to utilize the most common basic catalysts such as potassium or sodium hydroxide, oil has to be pretreated to reduce its acidity. Some researchers have investigated acid esterification of free fatty acids in order to deal with the acidity issue [22,23]. Kondamudi et al. removed free fatty acids by converting them into soap with a basic solution and then removed the soap by centrifuging the mixture for $30 \mathrm{~min}$ at $5000 \mathrm{rpm}$ [24].

Deep eutectic solvents (DESs) are mixtures of two or more components held together by hydrogen bonds. They are generally relatively easy and inexpensive to prepare and are widely known as environmentally friendly, non-toxic, non-flammable, and biodegradable solvents [25]. Concerning waste coffee grounds, deep eutectic solvents have been investigated for ultrasound-assisted extraction of bioactive compounds such as chlorogenic acids and flavonoids [26,27] and for pretreatment for enzymatic sugar production due to their ability to solubilize the lignin and increase the availability of the cellulose [28]. In the existing literature, deep eutectic solvents have been used in the biodiesel production process from various feedstocks as catalysts for the esterification step, solvents in biocatalytic transesterification, and for the purification of crude biodiesel [29-37].

The goal of this work was to utilize deep eutectic solvents in the process of biodiesel production from waste coffee grounds. The first step was the purification of WCG oil from FFAs via extractive deacidification with a potassium carbonate-based DES and the second step was extraction of glycerol and glycerides from crude biodiesel using a choline chloride-based DES. Feedstock pretreatment via extractive deacidification and utilization of deep eutectic solvents for this purpose is a novelty. Successful purification of both feedstock and crude biodiesel proved that the application of DESs in the processing of waste coffee grounds has exciting prospects.

\section{Materials and Methods}

\subsection{Chemicals}

All chemicals used in this work are listed in Table 1. 
Table 1. Chemicals used in this work.

\begin{tabular}{ccc}
\hline Chemical & Manufacturer & CAS Number \\
\hline Diethyl ether, p.a. & Honeywell & $60-29-7$ \\
Ethanol, p.a. & KEFO & $64-17-5$ \\
Ethylene glycol, p.a. & T.T.T. & $107-21-1$ \\
Choline chloride, 99\% & Acros Organics & $67-48-1$ \\
Methanol, HPLC grade & J.T. Baker & $67-56-1$ \\
$n$-hexane, p.a. & Carlo Erba & $110-54-3$ \\
Potassium carbonate, p.a. & Lach-Ner & $584-08-7$ \\
Potassium hydroxide, p.a. & Kemika & $1310-58-3$ \\
Potassium hydroxide 0.1N in ethanol & VWR Chemicals & \\
Sodium hydroxide, p.a. & T.T.T. & $1310-73-2$ \\
\hline
\end{tabular}

\subsection{Extraction of Oil from Waste Coffee Grounds}

Waste coffee grounds were collected from three different coffee bars that sold different types of coffee. Additional samples of waste and fresh coffee grounds were of household origin. Prior to oil extraction, waste coffee grounds were dried at $105^{\circ} \mathrm{C}$ in an atmospheric dryer. The Soxhlet method with $n$-hexane as the solvent was used for the extraction of oil from waste and fresh coffee grounds. Dry coffee grounds were weighed into a thimble and placed in the Soxhlet extractor. Oil was extracted with $1000 \mathrm{~mL}$ of $n$-hexane per $100 \mathrm{~g}$ of coffee under reflux for $2 \mathrm{~h}$. After extraction, $n$-hexane was removed by means of vacuum evaporation and stored for future use. Oil samples were taken in order to determine total acid number. Total acid number was determined titrimetrically, according to the standard method ISO 660:2009.

\subsection{Preparation of Deep Eutectic Solvents}

Before the preparation of deep eutectic solvents, hydrogen bond donors and hydrogen bond acceptors were vacuum dried in order to remove residual water. Hydrogen bond acceptors (choline chloride and potassium carbonate) and a hydrogen bond donor (ethylene glycol) were directly weighed in a round bottom flask and placed on a rotary vacuum evaporator equipped with a vacuum pump until a clear homogeneous liquid was obtained. Two DESs were prepared: (1) potassium carbonate:ethylene glycol, 1:10 molar ratio (DES1—used for extractive deacidification) and (2) choline chloride:ethylene glycol, 1.0:2.5 molar ratio (DES2—used for purification of biodiesel).

\subsection{Deacidification of Waste Coffee Grounds Oil}

Two methods were tested for lowering the concentration of FFA in the extracted oils: esterification with $\mathrm{H}_{2} \mathrm{SO}_{4}$ and extractive deacidification with DES1. Esterification was conducted for $2 \mathrm{~h}$ in a jacketed vessel (500 rpm) equipped with thermostat set at $60{ }^{\circ} \mathrm{C}$ and mass ratio of $\mathrm{H}_{2} \mathrm{SO}_{4}$, methanol, and oil equal to 1:40:100. Extraction experiments were performed in a batch extractor equipped with a temperature controlled magnetic stirrer (500 rpm) at $25^{\circ} \mathrm{C}$ and mass ratio of DES1 and oil equal to 0.1:1 for $1 \mathrm{~h}$. After deacidification, two-phase systems obtained after both methods were separated in the separating funnel. Deacidified oil was used for transesterification.

\subsection{Biodiesel Synthesis and Purification}

In the initial set of experiments, biodiesels were synthesized by the alkali-catalyzed transesterification of three different types of waste coffee ground oil (WCGO) with methanol at the mass ratio of catalyst, methanol and oil equal to 1:40:100. Sodium methoxide (BD1, BD2, BD3) or potassium methoxide (BD4) solution was prepared by dissolving $1 \mathrm{~g}$ of catalyst in $40 \mathrm{~g}$ of methanol and added to $100 \mathrm{~g}$ of WCGO heated at $60{ }^{\circ} \mathrm{C}$ and intensively mixed (500 rpm) for an hour in a vessel equipped with a temperature controlled magnetic stirrer. Reaction duration ranged from 30 to $90 \mathrm{~min}$. The heterogeneous mixture was separated by centrifugation. Glycerol and glycerides from 
crude biodiesels were removed by means of liquid-liquid extraction with DES2 under the following process conditions: mass ratio of DES2 and oil $=1: 1, T=25^{\circ} \mathrm{C}, n=500 \mathrm{rpm}, t=30,60$, and $90 \mathrm{~min}$. Additionally, the influence of the mass ratio of the catalyst $([0.1,0.5,1]: 40: 100)$, methanol, and oil $(0.5:[30,40,50]: 100)$ on the conversion of WCGO to biodiesel as well as the influence of the mass ratio of DES2 and biodiesel on the biodiesel composition were both tested. Finally, biodiesel was continuously purified using a Karr column. The column had 11 perforated plates spaced every $4 \mathrm{~cm}$ with a $22 \%$ plate free flow area and a plate diameter of $0.043 \mathrm{~m}$. Total height of the column was $0.75 \mathrm{~m}$, active height was $0.43 \mathrm{~m}$, its diameter was $0.05 \mathrm{~m}$, and it was equipped with two peristaltic pumps and two phase separators. Biodiesel was introduced at the bottom of the column and the DES was introduced near the top. Samples were taken from the separator every 5 min and analyzed.

\subsection{Coffee Ground Oil and Biodiesel Characterization}

Analytical methods used for characterization of all samples were Fourier transform infrared spectroscopy (FTIR), proton nuclear magnetic resonance spectroscopy $\left({ }^{1} \mathrm{H} \mathrm{NMR}\right)$, and gas chromatography (GC). FTIR spectra were recorded using a Bruker Vertex 70 spectrometer in FTIR ATR (attenuated total reflection) mode with a range of $4000-400 \mathrm{~cm}^{-1}$ (MIR). ${ }^{1} \mathrm{H}$ NMR spectra were recorded in deuterated chloroform with tetramethylsilane (TMS) as the internal standard on a Bruker Avance 300 Neo spectrometer. ${ }^{1} \mathrm{H}$ NMR was used to quantify the content of total fatty acid methyl esters (FAME). Integration values of the methyl ester signal at $3.66 \mathrm{ppm}$ (AMe) and of glyceridic signal in triglycerides at $2.30 \mathrm{ppm}(\mathrm{ACH} 2)$ were used for calculations. The equation used to quantify the yield of transesterification was:

$$
\% F A M E=100 \cdot \frac{2 \cdot A \mathrm{Me}}{3 \cdot A C H 2}
$$

Composition of FAME (Shimadzu GC-2014) as well as glycerol and glycerides (GC, Scion 436-GC) were determined by GC analysis.

Biodiesel samples were further analyzed at an accredited Central Testing Laboratory of INA-Industrija nafte d.d., Zagreb, Croatia.

\section{Results and Discussion}

\subsection{Deacidification of Waste and Fresh Coffee Ground Oils}

Wet waste coffee grounds were collected from three coffee bars and one household and dried until all water was removed. After extraction of oil from the different types of waste and one sample of freshly milled coffee grounds, the quantity of extracted oil and TAN of all oils were determined and presented in Table 2. The quantity of oil ranged from 11.28 to $14.85 \%$ in dried WCGOs and $16.22 \%$ in fresh coffee ground oil (FCGO), which was in concordance with the previously published data [23]. Slightly lower concentrations of oil in WCGOs can be attributed to the low extraction of lipids during preparation of the coffee beverage [38]. Since the TAN of all extracted oils was higher than $2 \mathrm{mg}$ $\mathrm{KOH} / \mathrm{g}$ oil, the concentration of FFA needed to be reduced. The concentration of FFA in all samples was significantly lower than that reported in the literature [23] due to the different types of coffee [5,39]. Campos, Vega, R. et al. reported in their review that the acid value of oils extracted in a laboratory usually ranges from 4 to $10 \mathrm{mg} \mathrm{KOH} / \mathrm{g}$ oil. For instance, based on the results by Chokchai Mueanmas et al., oil extracted from WCGO of a mixture of grounds from Arabica and Robusta coffee beans contained $16.5 \%$ of FFAs, which corresponded to an acid value of $32.84 \mathrm{mg} \mathrm{KOH} / \mathrm{g}$ of oil. The first employed method for lowering the concentration of FFAs was a commonly used method, esterification with $\mathrm{H}_{2} \mathrm{SO}_{4}$. This method successfully reduced TAN, however, it was not cost-effective since the reaction was conducted for two hours at elevated temperature. After one hour, TAN was reduced to $2.69 \mathrm{mg}$ $\mathrm{KOH} / \mathrm{g}$ oil. On the other hand, only $30 \mathrm{~min}$ at room temperature were sufficient to achieve TANs lower than $1 \mathrm{mg} \mathrm{KOH} / \mathrm{g}$ oil by means of extractive deacidification with DES based on potassium carbonate. Extraction efficiency ranged from 86.18 to $94.15 \%$. Deacidification by means of esterification with 
sulfuric acid was tested for one type of WCGO for comparison with the efficiencies obtained for WCGO and FCGO of different origins. Chokchai Mueanmas et al. reported esterification efficiencies from 65 to $94.79 \%$ for different reaction conditions [23]. Esterification efficiency obtained in this article fell within the range that can be found in the literature. Since sulfuric acid is a strong acid and the reaction is conducted under unfavorable conditions (increased temperature and longer reaction duration) when compared to deep eutectic solvents (green solvent) and mild extraction conditions (30 min, room temperature). The initial acid number of the used extracted oils ranged from 3.76 to $5.9 \mathrm{mg}$ $\mathrm{KOH} / \mathrm{g}$ oil. Different extraction efficiencies probably result from different compositions of the extracted oils. It was expected that the increase in the initial concentration of FFA will result in a higher extraction efficiency due to the higher driving force for mass transfer. Since the WCGOs are of different origin, and consequently different chemical composition, obviously some other components participated in mass transfer and effected the solubility of FFA in DES or the rate of mass transfer.

Table 2. Total acid number of waste (WCGO) and fresh (FCGO) coffee grounds oils before and after deacidification.

\begin{tabular}{|c|c|c|c|c|c|}
\hline \multirow{2}{*}{ Feedstock } & \multirow{2}{*}{$\begin{array}{c}\text { Extracted Oil, } \\
\%\end{array}$} & \multirow{2}{*}{$\begin{array}{l}\text { Deacidification } \\
\text { Method }\end{array}$} & \multicolumn{2}{|c|}{ TAN, mg KOH/g oil } & \multirow{2}{*}{$\begin{array}{c}\text { Extraction } \\
\text { Efficiency, \% }\end{array}$} \\
\hline & & & Initial & Purified & \\
\hline WCGO1 & 12.97 & $\begin{array}{l}\text { Esterification } \\
\text { with } \mathrm{H}_{2} \mathrm{SO}_{4}\end{array}$ & 5.50 & 0.73 & 86.73 \\
\hline WCGO2 & 11.28 & \multirow{4}{*}{$\begin{array}{c}\text { Extractive } \\
\text { deacidification } \\
\text { With DES } 1\end{array}$} & 3.76 & 0.22 & 94.15 \\
\hline WCGO3 & 11.50 & & 4.83 & 0.65 & 86.54 \\
\hline WCGO4 & 14.85 & & 5.90 & 0.57 & 90.33 \\
\hline FCGO5 & 16.22 & & 4.92 & 0.68 & 86.18 \\
\hline
\end{tabular}

The FTIR spectra of WCGO2 are shown in Figure 1. Some characteristic peaks can be observed: peaks between 3000 and $2800 \mathrm{~cm}^{-1}$ correspond to the aliphatic $\mathrm{CH}_{2}$ group; peaks at 2360.22 and $2341.17 \mathrm{~cm}^{-1}$ belong to $\mathrm{CO}_{2}$; the peak at $1743.62 \mathrm{~cm}^{-1}$ is attributed to the ester carbonyl groups of triglycerides. A weak shoulder at around $1710 \mathrm{~cm}^{-1}$ corresponds to the stretching vibration of the free fatty acid carbonyl group and the reduction of that peak (shown in the enlarged portion of the spectra, to the right) indicates that free fatty acids were extracted successfully. The absence of a peak at around $1570 \mathrm{~cm}^{-1}$ means that neutralization did not occur and that the reduction of free fatty acids is indeed due to extraction [40]. The peak at $1377.26 \mathrm{~cm}^{-1}$ corresponds to the glycerol group $\mathrm{O}-\mathrm{CH}_{2}$ of mono-, di-, and triglycerides [41].
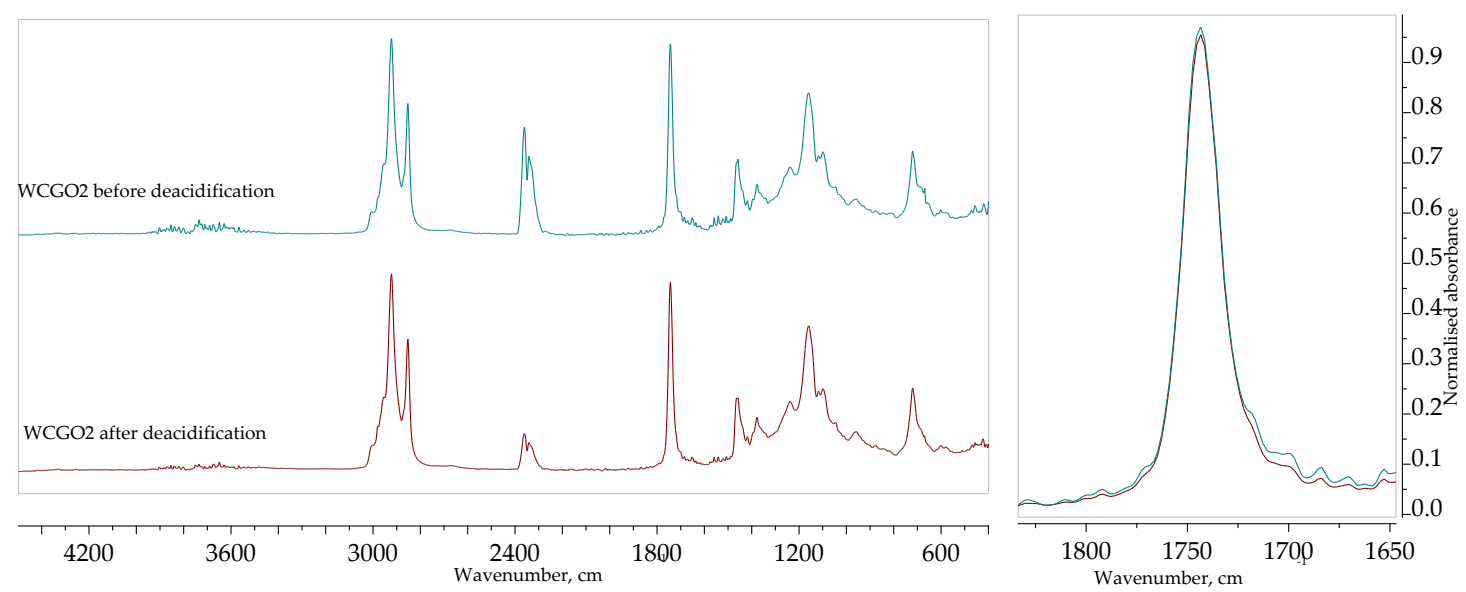

Figure 1. Fourier transform infrared (FTIR) spectra of WCGO2 before and after extraction with DES1 $\left(T=25^{\circ} \mathrm{C}, t=30 \mathrm{~min}, \mathrm{DES} 8 / \mathrm{oil}=0.1 / 1 \mathrm{w} / \mathrm{w}\right)$. 


\subsection{Selection of Optimal Process Conditions}

In the first set of experiments, purified WCGOs of different origins were used for biodiesel synthesis. BD1 was synthesized from WCGO1 and BD2 from WCGO2, while BD3 and BD4 were produced from WCGO3. Reaction conditions were: mass ratio catalyst:methanol:oil = 1.0:40:100; synthesis time, $60 \mathrm{~min}$; extraction time, $60 \mathrm{~min} .{ }^{1} \mathrm{H}$ NMR spectra of synthesized crude biodiesels (BD1, $\mathrm{BD} 2, \mathrm{BD} 2$, and BD4) are given in Figure 2. Aside from the signal characteristic for methyl ester at $3.66 \mathrm{ppm}$, the hydroxyl group signal from glycerol and methanol at around $3.44 \mathrm{ppm}$ could also be observed. The signals characteristic for kahweol $(5.87,5.91,6.19$, and $6.29 \mathrm{ppm})$ were found on all spectra [42]. This means that kahweol was also extracted with $n$-hexane from the waste coffee grounds. Signals in the range from 3.80 to $4.35 \mathrm{ppm}$ are attributed to unreacted mono-, di-, and triglycerides.
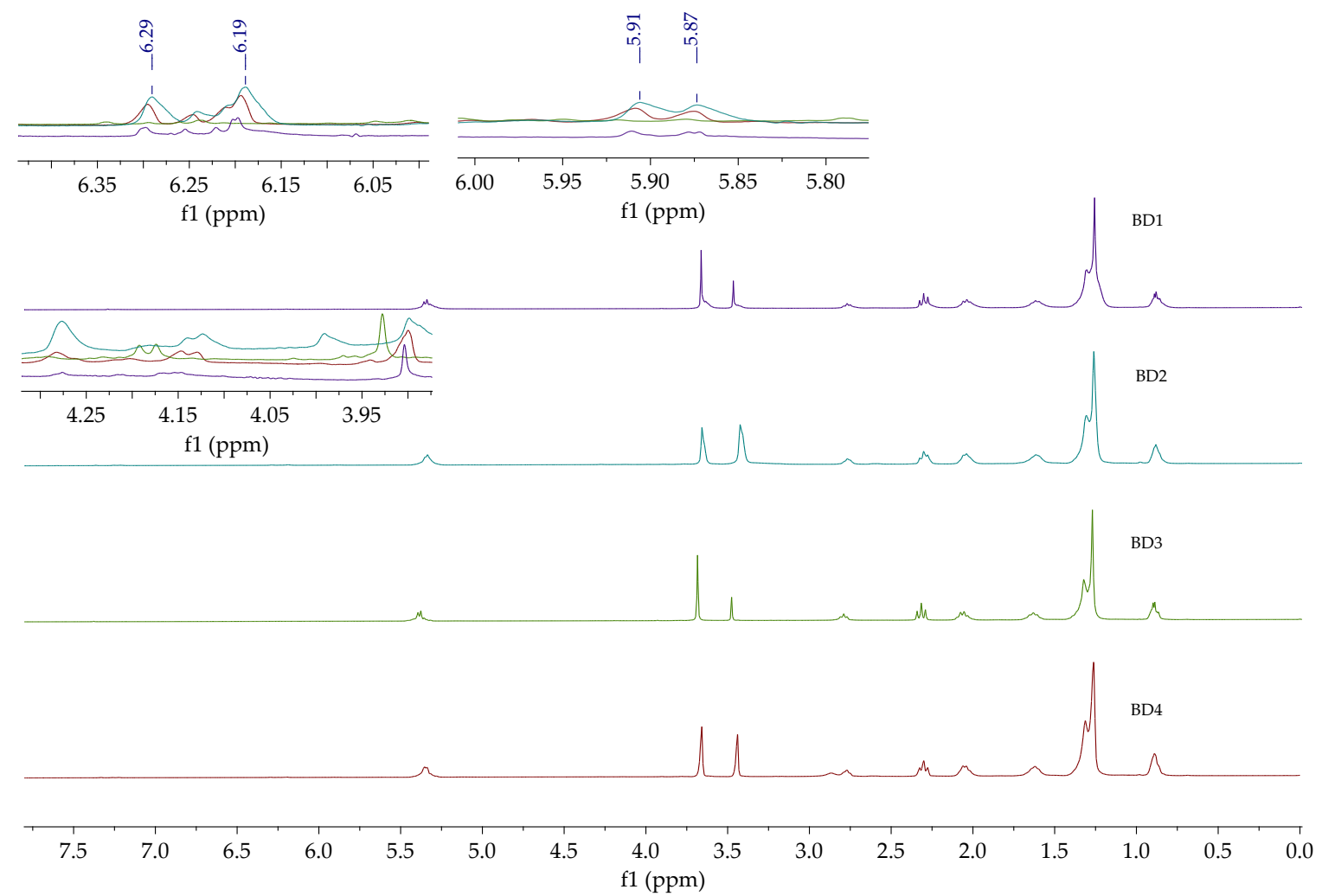

Figure 2. ${ }^{1} \mathrm{H}$ NMR spectra of crude biodiesels (BD1, BD2, BD3, and BD4).

Crude biodiesels were then purified by means of liquid-liquid extraction with DES based on choline chloride. Distributions of FAME in crude and purified biodiesels are given in Table 3. Based on the obtained results, it can be concluded that the type of coffee, deacidification method, and catalyst used for transesterification influenced the quality of the produced biodiesel. The concentration of FAME in the crude and purified biodiesels increased in the following order: BD2 $<$ BD1 $<$ BD3 $<$ BD4. It was obvious that not only the concentration of FFAs in oil influenced the quality of biodiesel. The lowest quality biodiesel (lowest concentration of FAME) was obtained from deacidified WCGO2, which had the lowest acid number. The most abundant FAME in all crude biodiesels was linoleic acid methyl ester (from 33.85 to $43.1 \%$ ), followed by palmitic acid methyl ester (from 26.31 to $33.6 \%$ ), oleic acid methyl ester (from 6.49 to $8.9 \%$ ), and stearic acid methyl ester (from 5.56 to $6.80 \%$ ). According to the published data reviewed by R. Campos-Vega, waste coffee grounds oils consist mostly of linoleic, palmitic, oleic, and stearic fatty acids. FAME profiles depend on the method and/or conditions of oil extraction, purification method, reaction conditions, and origin. In this study, oils were obtained by the same extraction method (Soxhlet extraction with $n$-hexane). The purification method did not significantly modify the composition of FAME. All biodiesels were produced at the same reaction conditions, so 
based on the results presented in this work, coffee origin plays a major role. Biodiesels BD3 and BD4 were of the same origin and the few FAME that were detected in other biodiesels were not detected in biodiesels obtained from WCGO3. It is possible that the concentration of those FAME (C8:0 up to C12:0, C16:1, C22:0, C22:6, C23:0) were below the detectable limit. In general, concentrations of different types of FAME in WCGO biodiesels were as follows: polyunsaturated FAME > monounsaturated FAME > saturated FAME. The increase in FAME concentration up to $4.2 \%$ after purification could be observed for lower quality biodiesels (BD1 and BD2). In contrast, the composition of purified biodiesel did not change significantly for higher quality biodiesels (BD3 and BD4). When $\mathrm{KOH}$ was used as the catalyst, the total FAME content in crude BD4 (97.3\%) was higher than in crude biodiesel BD3 (96.4\%), therefore, it can be concluded that $\mathrm{KOH}$ is a more effective catalyst than $\mathrm{NaOH}$. The presence of other components in extracted oil and FFA profiles influenced the conversion of triglycerides to FAME, in other words, the quality of biodiesel [13,39]. A concentration increase of FAME for biodiesels BD1 and $\mathrm{BD} 2$ can be attributed to the removal of glycerol and glycerides during the extraction step. In order to confirm this, the concentrations of glycerol and glycerides in crude and purified biodiesels (BD1) were measured and are presented in Figure 3. Bearing in mind that the concentration of free glycerol, mono-, di-, and triglycerides was reduced from 1.287 to $0.775 \%$, it is obvious that some other substances (excess catalyst, methanol, or some biocompounds characteristic for coffee oil) were extracted from crude biodiesel. Additional measurements of caffeine in crude and purified biodiesel confirmed that caffeine also participated in mass transfer. Concentration of caffeine was reduced from 0.46 to $0.40 \%$.

Table 3. Fatty acid methyl ester concentration in waste coffee grounds oil biodiesels before and after extraction.

\begin{tabular}{|c|c|c|c|c|c|c|c|c|c|c|}
\hline \multirow[b]{4}{*}{ FAME } & & \multicolumn{9}{|c|}{$\%$} \\
\hline & & $30 n$ & in Synt & esis & $60 n$ & in Synt & lesis & $90 \mathrm{n}$ & in Synt & lesis \\
\hline & & \multicolumn{9}{|c|}{ Extraction Time, min } \\
\hline & \multicolumn{2}{|c|}{ Structure 0} & 30 & 90 & 0 & 30 & 90 & 0 & 30 & 90 \\
\hline Caprylic acid methyl ester & C8:0 & 0.00 & 0.00 & 0.00 & 0.00 & 0.00 & 0.00 & 0.01 & 0.00 & 0.00 \\
\hline Capric acid methyl ester & $\mathrm{C} 10: 0$ & 0.00 & 0.00 & 0.00 & 0.00 & 0.00 & 0.00 & 0.00 & 0.00 & 0.00 \\
\hline Undecylic acid methyl ester & C11:0 & 0.00 & 0.00 & 0.00 & 0.00 & 0.01 & 0.00 & 0.01 & 0.01 & 0.00 \\
\hline Lauric acid methyl ester & $\mathrm{C} 12: 0$ & 0.01 & 0.01 & 0.01 & 0.01 & 0.01 & 0.01 & 0.01 & 0.01 & 0.01 \\
\hline Mystric acid methyl ester & C14:0 & 0.05 & 0.05 & 0.06 & 0.05 & 0.05 & 0.06 & 0.05 & 0.06 & 0.06 \\
\hline Tetradeceonic acid methyl ester & C14:1 & 0.00 & 0.00 & 0.01 & 0.00 & 0.00 & 0.00 & 0.00 & 0.00 & 0.00 \\
\hline Pentadecylic acid methyl ester & $\mathrm{C} 15: 0$ & 0.02 & 0.02 & 0.03 & 0.02 & 0.03 & 0.03 & 0.02 & 0.03 & 0.03 \\
\hline Palmitic acid methyl ester & $\mathrm{C} 16: 0$ & 26.42 & 28.61 & 29.42 & 26.34 & 29.64 & 29.34 & 26.08 & 29.70 & 29.84 \\
\hline Palmitoleic acid methyl ester & C16:1 & 0.02 & 0.03 & 0.03 & 0.02 & 0.03 & 0.03 & 0.02 & 0.03 & 0.03 \\
\hline Margaric acid methyl ester & $\mathrm{C} 17: 0$ & 0.12 & 0.10 & 0.10 & 0.13 & 0.10 & 0.10 & 0.13 & 0.10 & 0.10 \\
\hline Stearic acid methyl ester & C18:0 & 5.47 & 5.93 & 6.04 & 5.46 & 6.19 & 6.15 & 5.41 & 6.22 & 6.19 \\
\hline Oleic acid methyl ester & C18:1 & 6.19 & 6.71 & 6.84 & 6.15 & 6.96 & 6.90 & 6.11 & 7.01 & 6.99 \\
\hline Linoleic acid methyl ester & C18:2 & 34.49 & 37.28 & 37.88 & 34.13 & 38.51 & 38.22 & 33.99 & 39.05 & 38.83 \\
\hline Linolenic acid methyl ester & $\mathrm{C} 18: 3$ & 1.06 & 1.13 & 1.15 & 1.03 & 1.18 & 1.17 & 1.03 & 1.18 & 1.19 \\
\hline Arachidic acid methyl ester & C20:0 & 1.85 & 2.02 & 2.02 & 1.87 & 2.13 & 2.12 & 1.85 & 2.12 & 2.10 \\
\hline Paulinic acid methyl ester & C20:1 & 0.22 & 0.23 & 0.23 & 0.21 & 0.24 & 0.25 & 0.22 & 0.24 & 0.24 \\
\hline Eicosapentaenoic acid methyl ester & C20:5 & 0.06 & 0.07 & 0.07 & 0.06 & 0.07 & 0.07 & 0.01 & 0.07 & 0.07 \\
\hline Behenic acid methyl ester & $\mathrm{C} 22: 0$ & 0.01 & 0.01 & 0.01 & 0.01 & 0.02 & 0.01 & 0.39 & 0.01 & 0.01 \\
\hline Erucic acid methyl ester & C22:1 & 0.39 & 0.43 & 0.43 & 0.40 & 0.45 & 0.45 & 0.05 & 0.45 & 0.44 \\
\hline Docosahexaenoic acid methyl ester & $\mathrm{C} 22: 6$ & 0.00 & 0.04 & 0.01 & 0.00 & 0.00 & 0.01 & 0.06 & 0.01 & 0.01 \\
\hline Tricosylic acid methyl ester & $\mathrm{C} 23: 0$ & 0.05 & 0.06 & 0.05 & 0.00 & 0.06 & 0.06 & 0.05 & 0.06 & 0.06 \\
\hline Lignoceric acid methyl ester & C24:0 & 0.15 & 0.17 & 0.16 & 0.15 & 0.18 & 0.18 & 0.15 & 0.18 & 0.17 \\
\hline Nervonic acid methyl ester & $\mathrm{C} 24: 1$ & 0.01 & 0.01 & 0.08 & 0.01 & 0.01 & 0.01 & 0.01 & 0.01 & 0.01 \\
\hline Saturated & & 34.17 & 37.00 & 37.91 & 34.05 & 38.43 & 38.06 & 33.78 & 38.50 & 38.56 \\
\hline Monounsaturated & & 6.83 & 7.41 & 7.60 & 6.79 & 7.69 & 7.64 & 6.75 & 7.74 & 7.71 \\
\hline Polyunsaturated & & 35.61 & 38.51 & 39.11 & 35.22 & 39.75 & 39.47 & 35.09 & 40.31 & 40.10 \\
\hline Total FAME & & 76.61 & 82.92 & 84.61 & 76.06 & 85.88 & 85.16 & 75.62 & 86.55 & 86.36 \\
\hline
\end{tabular}

BD1: acid esterification followed by base transesterification (catalyst: $\mathrm{NaOH}$ ). BD2, BD3, BD4: extractive deacidification followed by base transesterification-different origin (catalyst (BD2, BD3): $\mathrm{NaOH}$; catalyst (BD4): $\mathrm{KOH})$. 


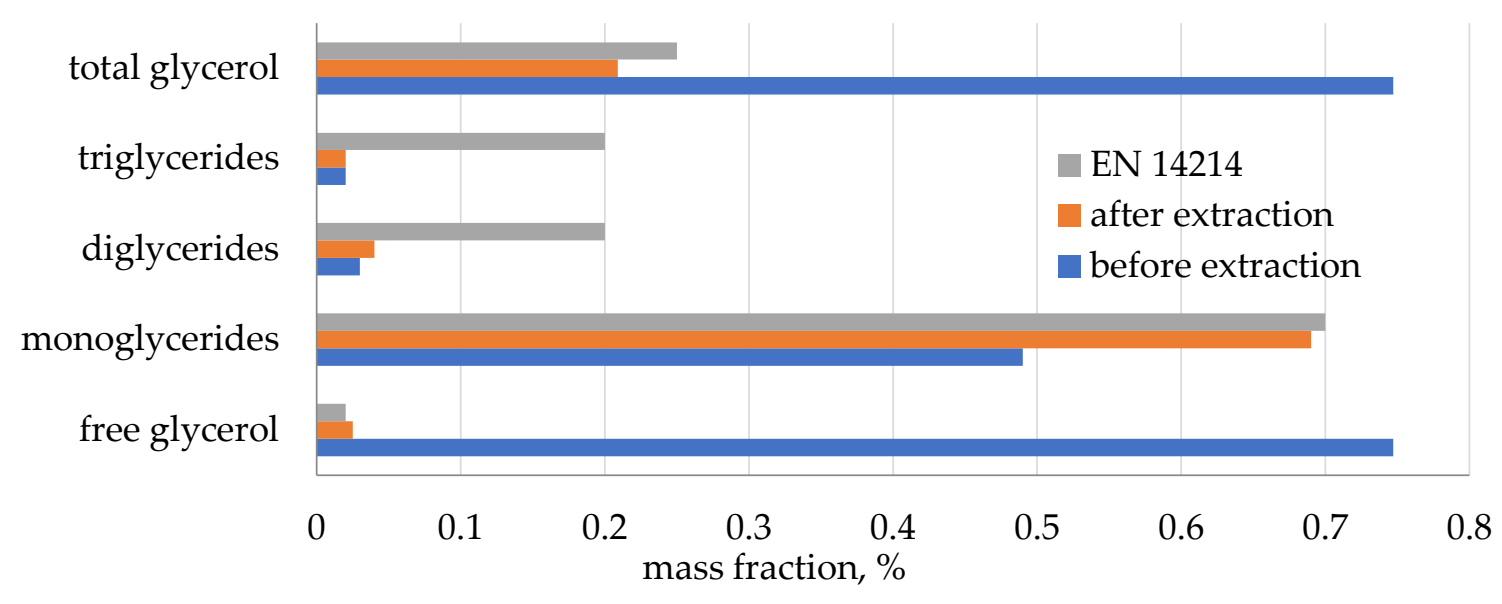

Figure 3. Concentration of glycerol and glycerides in crude and purified biodiesel (BD1).

${ }^{1} \mathrm{H}$ NMR spectra of deacidified oil (WCGO1), crude and purified biodiesel (BD1) are presented in Figure 4. Signals that corresponded to aliphatic protons in the region between 0 and $3 \mathrm{ppm}$ were visible in the ${ }^{1} \mathrm{H}$ NMR spectra of oil and biodiesels. Crude and purified biodiesel spectra contained a signal at $3.66 \mathrm{ppm}$ corresponding to the methyl ester group, while the deacidified oil spectrum contains signals in the region between 4.10 and $4.35 \mathrm{ppm}$ and $5.25 \mathrm{ppm}$, corresponding to glycerides. The intensity of the signal that corresponded to the hydroxyl group was significantly reduced, so it can be concluded that the selected DES is suitable for the extraction of glycerol as well as methanol from crude biodiesel.
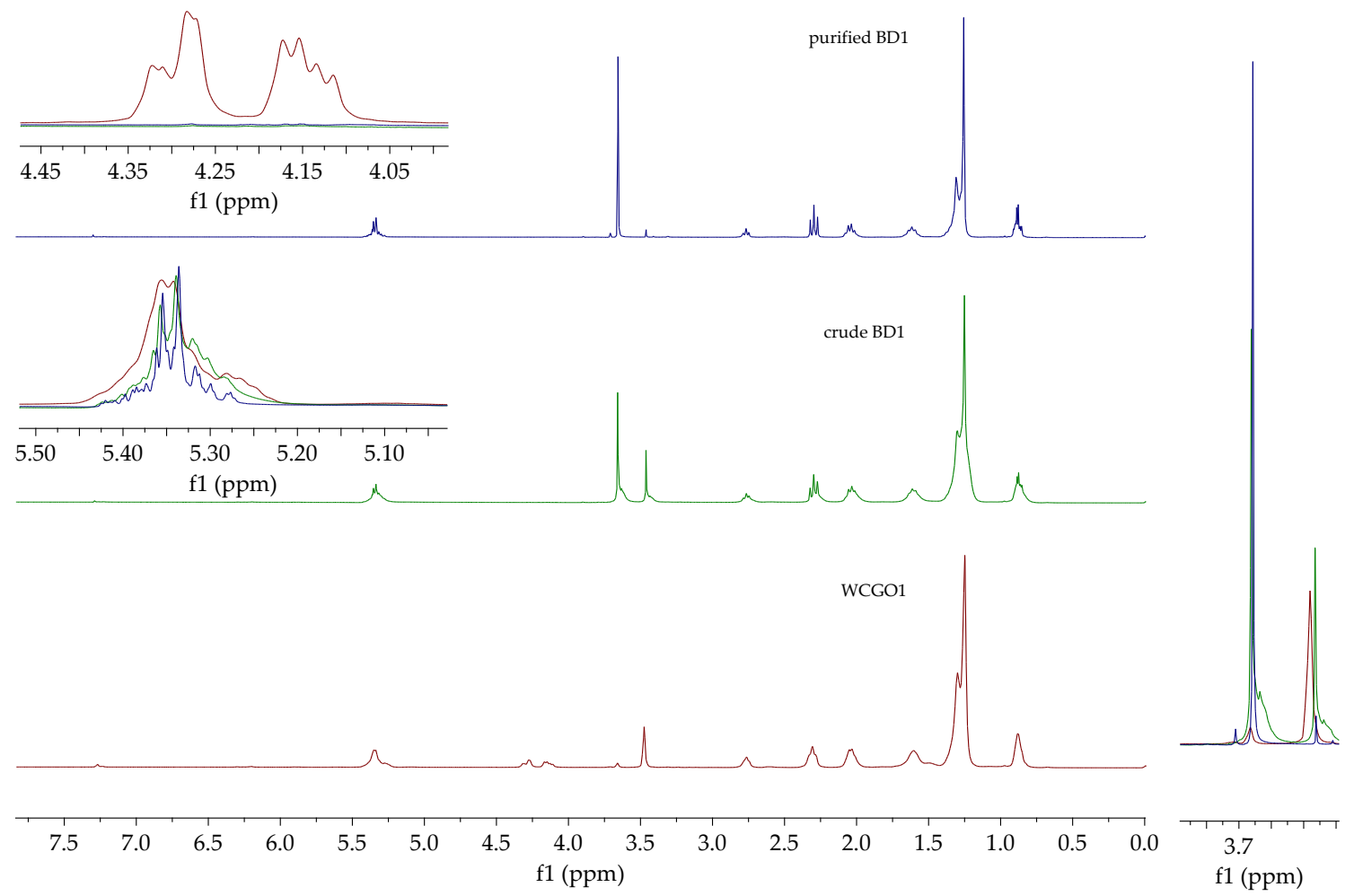

Figure 4. ${ }^{1} \mathrm{H}$ NMR spectra of deacidified oil (WCGO1), crude, and purified biodiesel (BD1).

The FTIR spectra shown in Figure 5 are characteristic for biodiesel samples with an ester group peak at $1741.65 \mathrm{~cm}^{-1},-\mathrm{CH}_{3}$ group peak at $1436.61 \mathrm{~cm}^{-1}$, and $\mathrm{O}-\mathrm{CH}_{3}$ group peak at $1196.90 \mathrm{~cm}^{-1}$. In the spectrum of unpurified biodiesel, a wide $-\mathrm{OH}$ peak between 3000 and $3600 \mathrm{~cm}^{-1}$ indicated the 
presence of alcohols, namely glycerol and methanol, and the peak at $1028.74 \mathrm{~cm}^{-1}$ corresponded to the $\mathrm{C}-\mathrm{O}$ stretching of methanol; both of these peaks are significantly reduced in the spectrum of purified biodiesel [43].

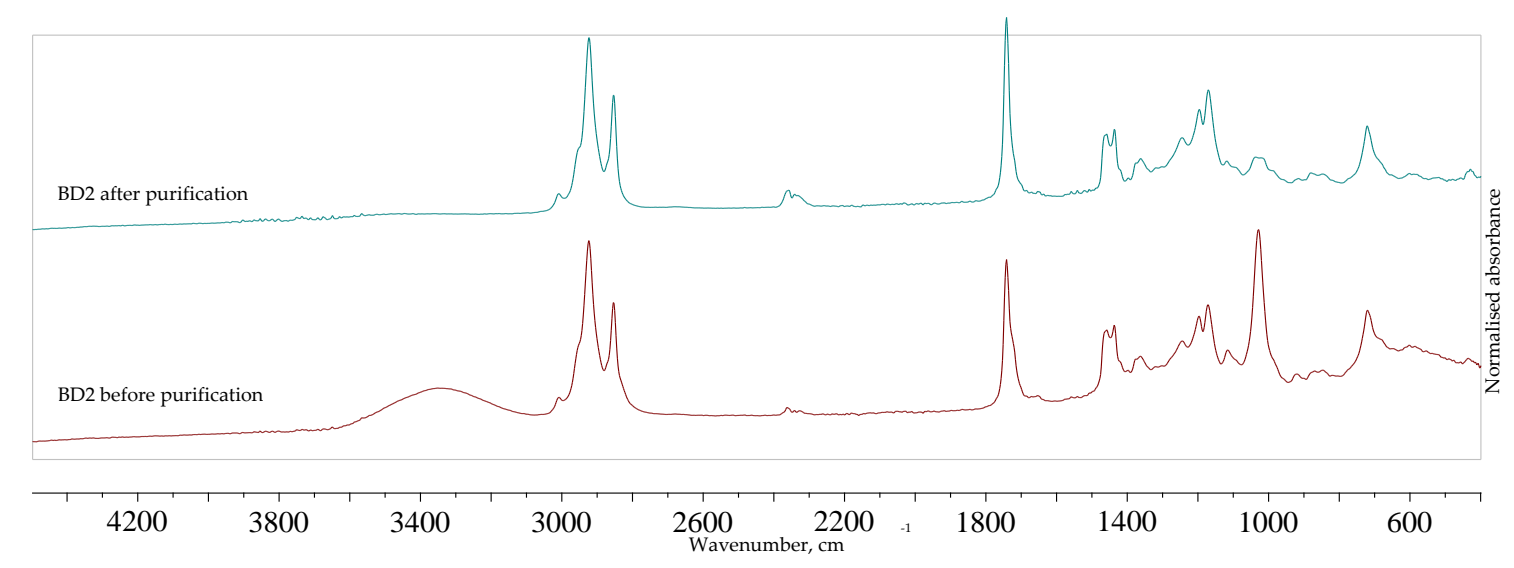

Figure 5. FTIR spectra of BD2 before and after extraction with DES2.

Since preliminary results with WCGO3 indicate that using $\mathrm{KOH}$ instead of $\mathrm{NaOH}$ did not significantly influence the FAME content in biodiesel, for the WCGO that produced the lowest quality biodiesel (WCGO2), the influence of mass ratio catalyst $(\mathrm{NaOH})$ :methanol:oil and extraction time with DES2 was investigated. FAME distributions in crude and purified biodiesels are presented in Table 4. The highest concentration of FAME was obtained for a mass ratio $\mathrm{NaOH}$ :methanol:WCGO2 equal to $0.5: 40: 100$ when the biodiesel yield was $78.60 \%$. A higher amount of catalyst did not enhance the reaction and the biodiesel yield was reduced. It is possible that a small amount of esters undergo the saponification reaction due to the presence of excess catalyst. However, all biodiesels contained a higher amount of FAME after extraction. Increasing the duration of the purification step from 30 to 90 min did not significantly influence the total FAME amount, therefore, the extraction time was set to $60 \mathrm{~min}$ for the other experiments.

The influence of reaction time on the conversion of the same WCGO2 to biodiesel and the purification time on the composition of biodiesel is presented in Table 5. For the investigated feedstock, the influence of reaction time on the conversion of oil to biodiesel could be neglected. Generally speaking, the influence of extraction duration on extraction efficiency could also be neglected since the total FAME content changed for a maximum of 1.69\% with increasing extraction time from 30 to $90 \mathrm{~min}$. These conclusions were derived from the high capacity of deep eutectic solvents for different types of solutes and it can be assumed that equilibrium is reached after a short extraction period. In some cases, a slight decrease in FAME concentration can be observed, most probably due to the dissolution of some esters in DES.

Since better results were obtained with $\mathrm{KOH}$ as the catalyst, the influence of mass ratio of catalyst, methanol, and WCGO3 (catalyst: $\mathrm{KOH}$, synthesis time, $60 \mathrm{~min}$; extraction time, $60 \mathrm{~min}$ ) on the FAME concentration of purified biodiesels was investigated. Based on the obtained results given in Table 6, it can be concluded that the mass ratio of catalyst, methanol, and WCGO3 did not influence the biodiesel yield significantly for the given range of reaction conditions. For all biodiesels, the concentration of FAME satisfied the biodiesel quality standard ( $>96.5 \%$ FAME) after the purification step. The highest concentration of FAME (98.0\%) was obtained when $0.5 \mathrm{~g}$ of $\mathrm{KOH}$ and 40 and $50 \mathrm{~g}$ of methanol were used for transesterification of $100 \mathrm{~g}$ of oil. 
Table 4. Fatty acid methyl ester concentration in waste coffee grounds oil biodiesels before and after extraction of WCGO2: Influence of mass ratio of catalyst, methanol, and WCGO and extraction time (synthesis time, $60 \mathrm{~min}$ ).

\begin{tabular}{|c|c|c|c|c|c|c|c|c|c|c|}
\hline \multirow[b]{3}{*}{ Extraction Time, min } & & \multicolumn{9}{|c|}{ Mass Ratio Catalyst:Methanol:WCGO } \\
\hline & & \multicolumn{3}{|c|}{ 0.1:40:100 } & \multicolumn{3}{|c|}{$0.5: 40: 100$} & \multicolumn{3}{|c|}{ 1.0:40:100 } \\
\hline & & 0 & 30 & 90 & 0 & 30 & 90 & 0 & 30 & 90 \\
\hline FAME & \multicolumn{2}{|c|}{ Structure } & & & & $\%$ & & & & \\
\hline Caprylic acid methyl ester & $\mathrm{C} 8: 0$ & 0.00 & 0.00 & 0.00 & 0.00 & 0.01 & 0.01 & 0.01 & 0.00 & 0.01 \\
\hline Capric acid methyl ester & C10:0 & 0.00 & 0.00 & 0.00 & 0.00 & 0.00 & 0.00 & 0.00 & 0.01 & 0.00 \\
\hline Undecylic acid methyl ester & C11:0 & 0.00 & 0.01 & 0.00 & 0.01 & 0.06 & 0.01 & 0.01 & 0.01 & 0.01 \\
\hline Lauric acid methyl ester & C12:0 & 0.01 & 0.01 & 0.01 & 0.01 & 0.02 & 0.01 & 0.02 & 0.01 & 0.01 \\
\hline Mystric acid methyl ester & C14:0 & 0.05 & 0.05 & 0.06 & 0.05 & 0.06 & 0.06 & 0.06 & 0.05 & 0.05 \\
\hline Tetradeceonic acid methyl ester & C14:1 & 0.00 & 0.00 & 0.00 & 0.00 & 0.01 & 0.00 & 0.00 & 0.00 & 0.01 \\
\hline Pentadecylic acid methyl ester & C15:0 & 0.02 & 0.03 & 0.03 & 0.03 & 0.03 & 0.05 & 0.04 & 0.02 & 0.03 \\
\hline Palmitic acid methyl ester & $\mathrm{C} 16: 0$ & 26.34 & 29.64 & 29.34 & 27.49 & 30.95 & 29.22 & 26.31 & 27.43 & 28.49 \\
\hline Palmitoleic acid methyl ester & C16:1 & 0.02 & 0.03 & 0.03 & 0.02 & 0.03 & 0.03 & 0.02 & 0.02 & 0.00 \\
\hline Margaric acid methyl ester & C17:0 & 0.13 & 0.10 & 0.10 & 0.10 & 0.11 & 0.10 & 0.11 & 0.10 & 0.10 \\
\hline Stearic acid methyl ester & C18:0 & 5.46 & 6.19 & 6.15 & 5.65 & 6.38 & 6.14 & 5.56 & 5.83 & 6.03 \\
\hline Oleic acid methyl ester & C18:1 & 6.15 & 6.96 & 6.90 & 6.62 & 7.46 & 7.16 & 6.49 & 6.46 & 6.69 \\
\hline Linoleic acid methyl ester & $\mathrm{C} 18: 2$ & 34.13 & 38.51 & 38.22 & 34.58 & 38.59 & 36.97 & 33.85 & 35.10 & 36.35 \\
\hline Linolenic acid methyl ester & $\mathrm{C} 18: 3$ & 1.03 & 1.18 & 1.17 & 1.06 & 1.17 & 1.11 & 1.03 & 1.06 & 1.09 \\
\hline Arachidic acid methyl ester & C20:0 & 1.87 & 2.13 & 2.12 & 1.98 & 2.21 & 2.17 & 1.99 & 2.10 & 2.15 \\
\hline Paulinic acid methyl ester & C20:1 & 0.21 & 0.24 & 0.25 & 0.22 & 0.27 & 0.24 & 0.22 & 0.23 & 0.24 \\
\hline Eicosapentaenoic acid methyl ester & C20:5 & 0.06 & 0.07 & 0.07 & 0.06 & 0.07 & 0.07 & 0.07 & 0.07 & 0.07 \\
\hline Behenic acid methyl ester & $\mathrm{C} 22: 0$ & 0.01 & 0.02 & 0.01 & 0.01 & 0.01 & 0.01 & 0.01 & 0.01 & 0.01 \\
\hline Erucic acid methyl ester & $\mathrm{C} 22: 1$ & 0.40 & 0.45 & 0.45 & 0.43 & 0.51 & 0.47 & 0.44 & 0.46 & 0.47 \\
\hline Docosahexaenoic acid methyl ester & $\mathrm{C} 22: 6$ & 0.00 & 0.00 & 0.01 & 0.01 & 0.01 & 0.01 & 0.01 & 0.01 & 0.01 \\
\hline Tricosylic acid methyl ester & C23:0 & 0.00 & 0.06 & 0.06 & 0.06 & 0.00 & 0.01 & 0.00 & 0.00 & 0.04 \\
\hline Lignoceric acid methyl ester & C24:0 & 0.15 & 0.18 & 0.18 & 0.16 & 0.18 & 0.19 & 0.17 & 0.18 & 0.19 \\
\hline Nervonic acid methyl ester & C24:1 & 0.01 & 0.01 & 0.01 & 0.01 & 0.01 & 0.01 & 0.01 & 0.01 & 0.00 \\
\hline Saturated & & 34.05 & 38.43 & 38.06 & 35.58 & 40.03 & 37.96 & 34.28 & 35.75 & 37.13 \\
\hline Monounsaturated & & 6.79 & 7.69 & 7.64 & 7.31 & 8.29 & 7.91 & 7.18 & 7.19 & 7.40 \\
\hline Polyunsaturated & & 35.22 & 39.75 & 39.47 & 35.71 & 39.84 & 38.16 & 34.96 & 36.25 & 37.52 \\
\hline Total FAME & & 76.06 & 85.88 & 85.16 & 78.60 & 88.15 & 84.03 & 76.42 & 79.19 & 82.06 \\
\hline
\end{tabular}

Table 5. Fatty acid methyl ester concentration in waste coffee grounds oil biodiesels before and after extraction WCGO2: Influence of synthesis and extraction time (mass ratio of catalyst $(\mathrm{NaOH})$, methanol, and oil $=0.1: 40: 100)$.

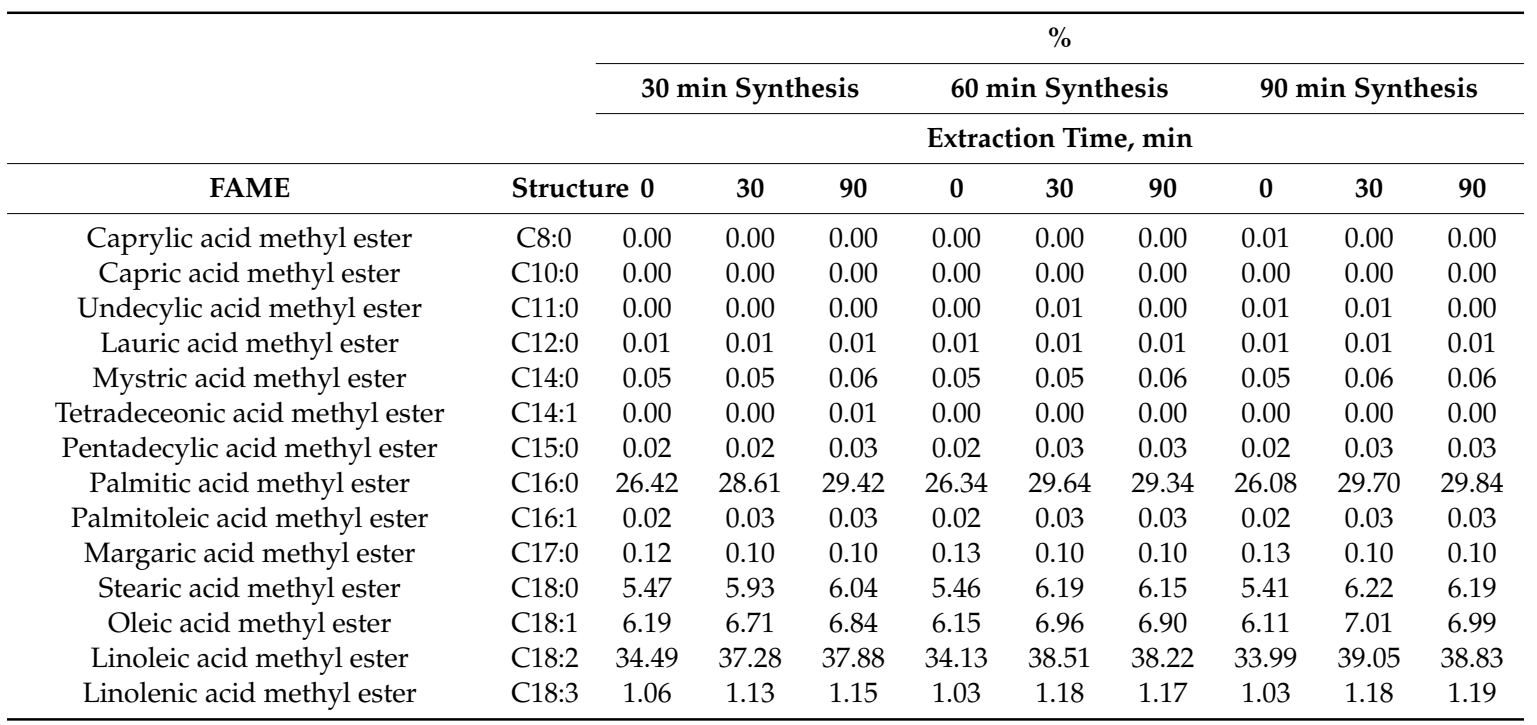


Table 5. Cont.

\begin{tabular}{|c|c|c|c|c|c|c|c|c|c|c|}
\hline \multirow[b]{4}{*}{ FAME } & & \multicolumn{9}{|c|}{$\%$} \\
\hline & & $30 \mathrm{~m}$ & n Synt & esis & $60 n$ & in Synt & lesis & $90 \mathrm{n}$ & n Synt & esis \\
\hline & & \multicolumn{9}{|c|}{ Extraction Time, min } \\
\hline & \multicolumn{2}{|c|}{ Structure 0} & 30 & 90 & 0 & 30 & 90 & 0 & 30 & 90 \\
\hline Arachidic acid methyl ester & C20:0 & 1.85 & 2.02 & 2.02 & 1.87 & 2.13 & 2.12 & 1.85 & 2.12 & 2.10 \\
\hline Paulinic acid methyl ester & C20:1 & 0.22 & 0.23 & 0.23 & 0.21 & 0.24 & 0.25 & 0.22 & 0.24 & 0.24 \\
\hline Eicosapentaenoic acid methyl ester & C20:5 & 0.06 & 0.07 & 0.07 & 0.06 & 0.07 & 0.07 & 0.01 & 0.07 & 0.07 \\
\hline Behenic acid methyl ester & C22:0 & 0.01 & 0.01 & 0.01 & 0.01 & 0.02 & 0.01 & 0.39 & 0.01 & 0.01 \\
\hline Erucic acid methyl ester & C22:1 & 0.39 & 0.43 & 0.43 & 0.40 & 0.45 & 0.45 & 0.05 & 0.45 & 0.44 \\
\hline Docosahexaenoic acid methyl ester & C22:6 & 0.00 & 0.04 & 0.01 & 0.00 & 0.00 & 0.01 & 0.06 & 0.01 & 0.01 \\
\hline Tricosylic acid methyl ester & C23:0 & 0.05 & 0.06 & 0.05 & 0.00 & 0.06 & 0.06 & 0.05 & 0.06 & 0.06 \\
\hline Lignoceric acid methyl ester & C24:0 & 0.15 & 0.17 & 0.16 & 0.15 & 0.18 & 0.18 & 0.15 & 0.18 & 0.17 \\
\hline Nervonic acid methyl ester & C24:1 & 0.01 & 0.01 & 0.08 & 0.01 & 0.01 & 0.01 & 0.01 & 0.01 & 0.01 \\
\hline Saturated & & 34.17 & 37.00 & 37.91 & 34.05 & 38.43 & 38.06 & 33.78 & 38.50 & 38.56 \\
\hline Monounsaturated & & 6.83 & 7.41 & 7.60 & 6.79 & 7.69 & 7.64 & 6.75 & 7.74 & 7.71 \\
\hline Polyunsaturated & & 35.61 & 38.51 & 39.11 & 35.22 & 39.75 & 39.47 & 35.09 & 40.31 & 40.10 \\
\hline Total FAME & & 76.61 & 82.92 & 84.61 & 76.06 & 85.88 & 85.16 & 75.62 & 86.55 & 86.36 \\
\hline
\end{tabular}

Table 6. Fatty acid methyl ester concentration in waste coffee grounds oil biodiesel WCGO3: Influence of mass ratio of catalyst, methanol, and WCGO (catalyst: $\mathrm{KOH}$, synthesis time, $60 \mathrm{~min}$; extraction time, $60 \mathrm{~min})$.

\begin{tabular}{|c|c|c|c|c|c|c|}
\hline \multirow[b]{3}{*}{ FAME } & \multirow[b]{3}{*}{ Structure } & \multicolumn{5}{|c|}{ Mass Ratio Catalyst (KOH):Methanol:WCGO } \\
\hline & & 0.1:40:100 & 0.5:40:100 & 1.0:40:100 & $0.5: 30: 100$ & $0.5: 50: 100$ \\
\hline & & \multicolumn{5}{|c|}{$\%$} \\
\hline Caprylic acid methyl ester & $\mathrm{C} 8: 0$ & 0.00 & 0.00 & 0.00 & 0.00 & 0.00 \\
\hline Capric acid methyl ester & C10:0 & 0.00 & 0.00 & 0.00 & 0.00 & 0.00 \\
\hline Undecylic acid methyl ester & C11:0 & 0.00 & 0.00 & 0.00 & 0.00 & 0.00 \\
\hline Lauric acid methyl ester & $\mathrm{C} 12: 0$ & 0.00 & 0.00 & 0.00 & 0.00 & 0.00 \\
\hline Mystric acid methyl ester & C14:0 & 0.10 & 0.10 & 0.10 & 0.10 & 0.10 \\
\hline Tetradeceonic acid methyl ester & C14:1 & 0.00 & 0.00 & 0.00 & 0.00 & 0.00 \\
\hline Pentadecylic acid methyl ester & C15:0 & 0.10 & 0.10 & 0.10 & 0.10 & 0.10 \\
\hline Palmitic acid methyl ester & $\mathrm{C} 16: 0$ & 33.50 & 34.00 & 33.60 & 34.00 & 33.90 \\
\hline Palmitoleic acid methyl ester & C16:1 & 0.00 & 0.00 & 0.00 & 0.00 & 0.00 \\
\hline Margaric acid methyl ester & $\mathrm{C} 17: 0$ & 0.10 & 0.10 & 0.10 & 0.10 & 0.10 \\
\hline Stearic acid methyl ester & C18:0 & 6.70 & 6.70 & 6.80 & 6.60 & 6.80 \\
\hline Oleic acid methyl ester & C18:1 & 8.70 & 9.30 & 8.90 & 9.20 & 9.30 \\
\hline Linoleic acid methyl ester & C18:2 & 43.60 & 43.20 & 43.10 & 43.30 & 43.10 \\
\hline Linolenic acid methyl ester & C18:3 & 1.10 & 1.10 & 1.10 & 1.10 & 1.10 \\
\hline Arachidic acid methyl ester & C20:0 & 2.40 & 2.40 & 2.50 & 2.30 & 2.50 \\
\hline Paulinic acid methyl ester & C20:1 & 0.30 & 0.30 & 0.30 & 0.30 & 0.30 \\
\hline Eicosapentaenoic acid methyl ester & C20:5 & 0.10 & 0.10 & 0.10 & 0.10 & 0.10 \\
\hline Behenic acid methyl ester & $\mathrm{C} 22: 0$ & 0.00 & 0.00 & 0.00 & 0.00 & 0.00 \\
\hline Erucic acid methyl ester & C22:1 & 0.40 & 0.40 & 0.50 & 0.40 & 0.40 \\
\hline Docosahexaenoic acid methyl ester & $\mathrm{C} 22: 6$ & 0.00 & 0.00 & 0.00 & 0.00 & 0.00 \\
\hline Tricosylic acid methyl ester & C23:0 & 0.00 & 0.00 & 0.00 & 0.00 & 0.00 \\
\hline Lignoceric acid methyl ester & C24:0 & 0.20 & 0.20 & 0.20 & 0.20 & 0.20 \\
\hline Nervonic acid methyl ester & C24:1 & 0.00 & 0.00 & 0.00 & 0.00 & 0.00 \\
\hline Saturated & & 43.10 & 43.60 & 43.40 & 43.40 & 43.70 \\
\hline Monounsaturated & & 9.40 & 10.00 & 9.70 & 9.90 & 10.00 \\
\hline Polyunsaturated & & 44.80 & 44.40 & 44.20 & 44.50 & 44.30 \\
\hline Total FAME & & 97.30 & 98.00 & 97.30 & 97.80 & 98.00 \\
\hline
\end{tabular}


Finally, biodiesel was produced from fresh and waste coffee grounds (household coffee) of the same type of coffee, and the FAME concentrations in the purified biodiesels are given in Table 7 $(\mathrm{KOH}$ :methanol:oil $=0.5: 40: 100$; synthesis time, $60 \mathrm{~min}$; extraction time, $60 \mathrm{~min})$. Total FAME content was the same for fresh and waste coffee grounds. However, the concentration of glycerides and glycerol was different. Crude biodiesel produced from fresh coffee grounds contains more free glycerol and diglycerides and significantly less triglycerides than crude biodiesel produced from waste coffee grounds (Figure 6). Coffee contains different types of lipids (triglycerides, esters of diterpene alcohols and fatty acids, diterpene alcohols, esters of sterols and fatty acids, sterols, tocopherols, phosphatides and tryptamine derivatives) [1]. During beverage preparation, water soluble lipids, like diterpens, are partially extracted, so it can be expected that the content of glycerides is different. Chlorogenic acids, a class of water soluble esters, and related compounds are the main phenolic compounds in green and roasted coffee [44] as well as in waste coffee grounds [45]. Phenolic compounds present in WCGO and FCGO can also be extracted during the extraction of oil with $n$-hexane [46]. It was also reported that phenolic compounds are soluble in deep eutectic solvents and therefore these compounds can be extracted from biodiesel during the purification step [47,48]. Häkkinen and Abbott reported that different types of carbohydrates were soluble in choline chloride-based DESs. Some other compounds present in SCG, like terpenoids, can also be extracted with $n$-hexane [49]. Figure 7 shows that the ${ }^{1} \mathrm{H}$ NMR spectra of fresh and waste coffee grounds oil differed mostly in the intensity of signals that correspond to caffeine at: $3.39,3.57,3.98$, and 7.55 ppm [42].

Table 7. Fatty acid methyl ester concentration in fresh and waste coffee grounds oil purified biodiesels BD5 and BD6 (household).

\begin{tabular}{|c|c|c|c|}
\hline & & Fresh & Waste \\
\hline FAME & Structure & & \\
\hline Caprylic acid methyl ester & $\mathrm{C} 8: 0$ & 0 & 0 \\
\hline Capric acid methyl ester & C10:0 & 0 & 0 \\
\hline Undecylic acid methyl ester & $\mathrm{C} 11: 0$ & 0 & 0 \\
\hline Lauric acid methyl ester & $\mathrm{C} 12: 0$ & 0 & 0 \\
\hline Mystric acid methyl ester & C14:0 & 0.1 & 0.1 \\
\hline Tetradeceonic acid methyl ester & C14:1 & 0 & 0 \\
\hline Pentadecylic acid methyl ester & C15:0 & 0 & 0 \\
\hline Palmitic acid methyl ester & $\mathrm{C} 16: 0$ & 33.4 & 33.4 \\
\hline Palmitoleic acid methyl ester & C16:1 & 0 & 0 \\
\hline Margaric acid methyl ester & $\mathrm{C} 17: 0$ & 0.1 & 0.1 \\
\hline Stearic acid methyl ester & C18:0 & 6.8 & 7.0 \\
\hline Oleic acid methyl ester & C18:1 & 10.0 & 10.2 \\
\hline Linoleic acid methyl ester & C18:2 & 42.5 & 42.3 \\
\hline Linolenic acid methyl ester & C18:3 & 0.9 & 0.9 \\
\hline Arachidic acid methyl ester & $\mathrm{C} 20: 0$ & 2.6 & 2.6 \\
\hline Paulinic acid methyl ester & C20:1 & 0.3 & 0.3 \\
\hline Eicosapentaenoic acid methyl ester & C20:5 & 0.2 & 0.1 \\
\hline Behenic acid methyl ester & C22:0 & 0 & 0 \\
\hline Erucic acid methyl ester & $\mathrm{C} 22: 1$ & 0.4 & 0.4 \\
\hline Docosahexaenoic acid methyl ester & $\mathrm{C} 22: 6$ & 0 & 0 \\
\hline Tricosylic acid methyl ester & C23:0 & 0 & 0 \\
\hline Lignoceric acid methyl ester & $\mathrm{C} 24: 0$ & 0.2 & 0.2 \\
\hline Nervonic acid methyl ester & C24:1 & 0 & 0 \\
\hline Saturated & & 43.2 & 43.4 \\
\hline Monounsaturated & & 10.5 & 10.6 \\
\hline Polyunsaturated & & 43.6 & 43.3 \\
\hline Total FAME & & 97.3 & 97.3 \\
\hline
\end{tabular}




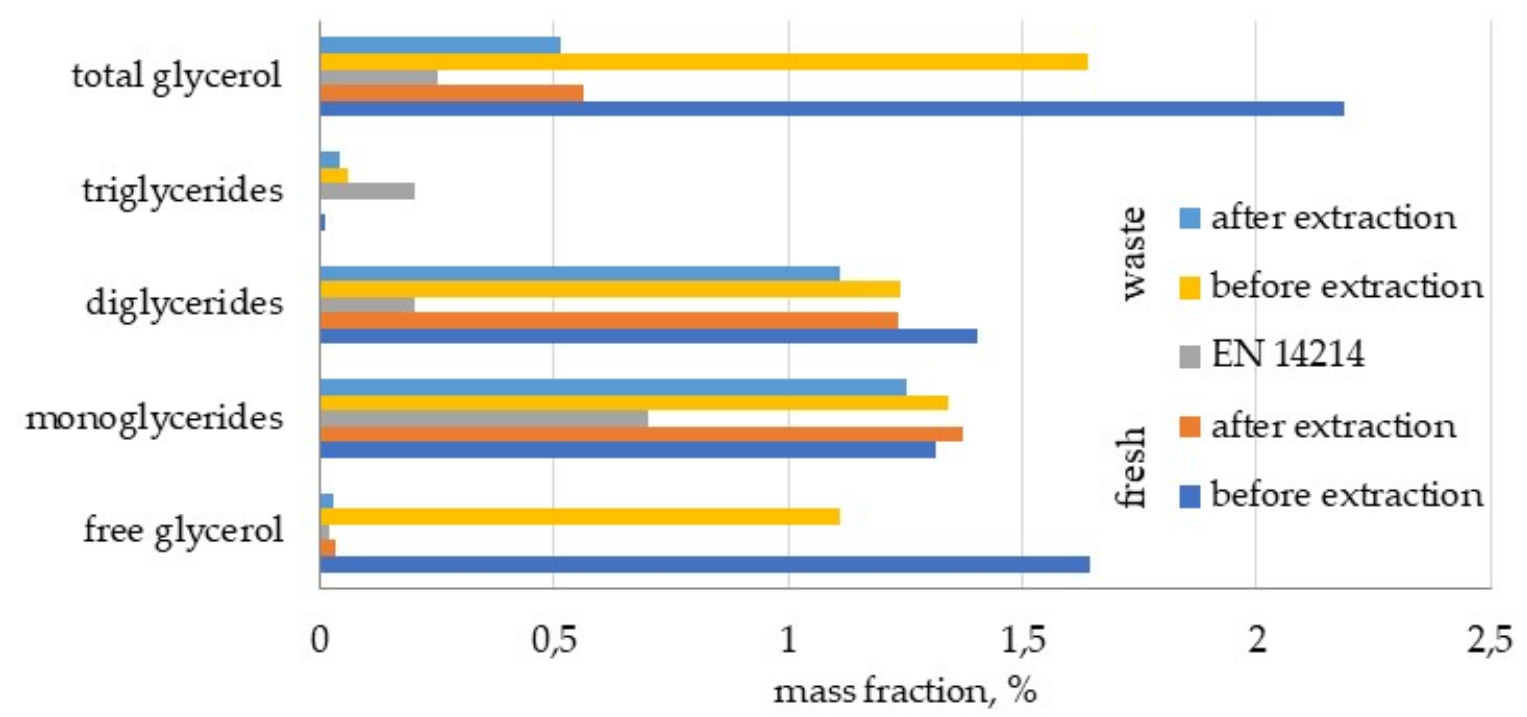

Figure 6. Concentration of glycerol and glycerides in crude and purified biodiesel (BD5 and BD6-household coffee).
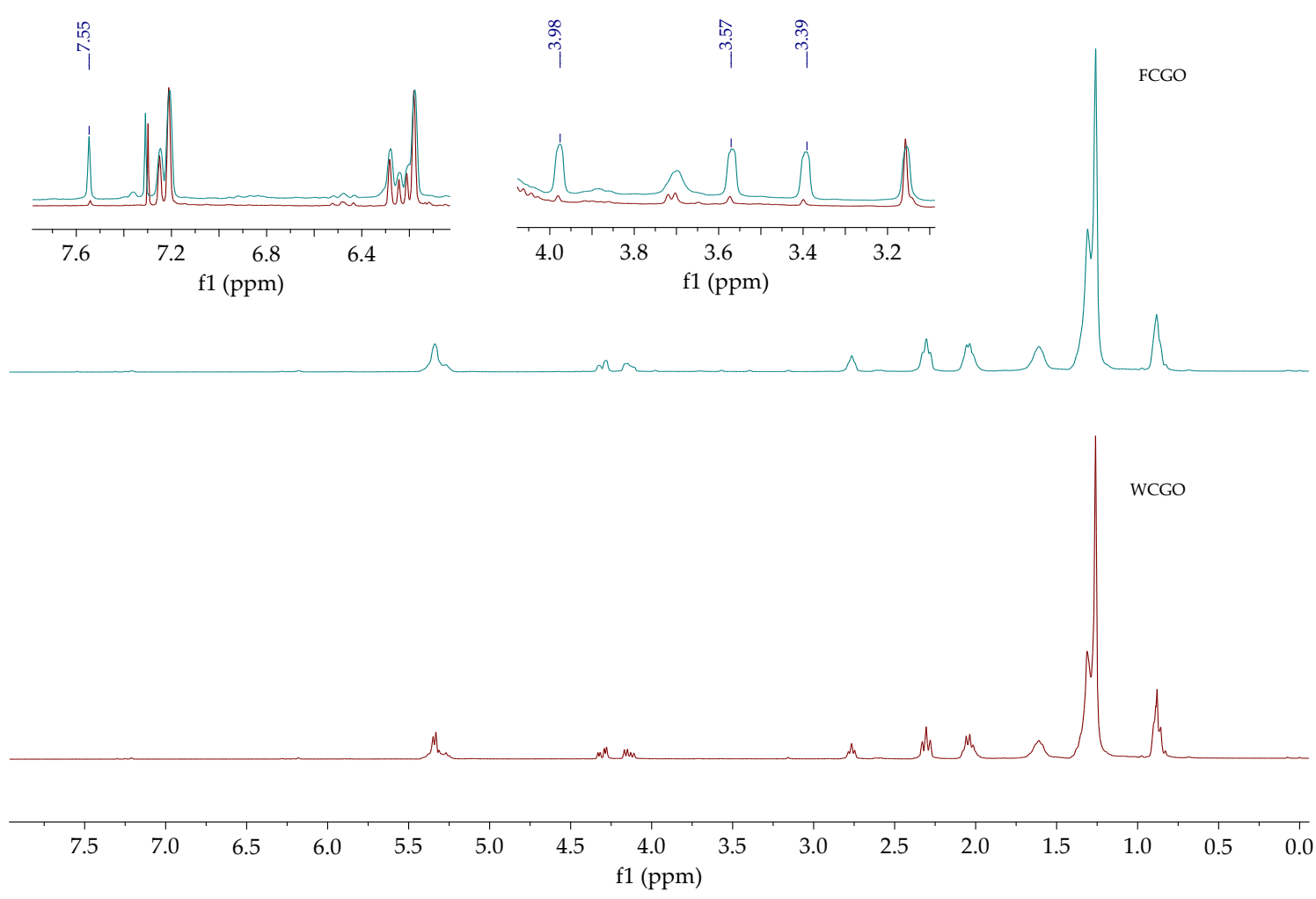

Figure 7. ${ }^{1} \mathrm{H}$ NMR spectra of fresh (FCGO) and waste (WCGO) coffee grounds oils.

Based on the obtained results, it is obvious that the origin of the coffee influences the quality of the synthesized biodiesel. This means that the optimal reaction conditions have to be determined experimentally for each type of coffee. However, some general conclusions can be drawn. The best mass ratio of catalyst:methanol:oil is 0.5:40:100. Too low a mass of the catalyst may not be enough for a high yield of biodiesel, while excess catalyst can induce saponification of FAME. Too low a mass of methanol may not be enough for the high conversion of oil to biodiesel. If the reaction is conducted with a high excess of methanol, the concentration of residual methanol in biodiesel can be 
too high, which can lower the flashpoint of biodiesel. Reaction time can be set to $60 \mathrm{~min}$ in order to ensure the maximum possible yield of biodiesel, and the extraction time can be set to $60 \mathrm{~min}$ to be sure that equilibrium (for transfer of glycerol, methanol and catalyst from crude biodiesel to DES) is achieved. Finally, since a higher conversion of oil to biodiesel was achieved with $\mathrm{KOH}$ as well as a better solubility of $\mathrm{KOH}$ in methanol, $\mathrm{KOH}$ was selected as the better catalyst.

\subsection{Purification of Crude Biodiesel in Continuous Column Extractor}

Following the batch extraction experiments, the possibility of purification of crude biodiesel by countercurrent column extraction was investigated. Biodiesel was synthesized from WCGO3 under optimal process conditions determined based on batch experiments ( $\mathrm{KOH}$ :methanol:oil = 0.5:40:100; synthesis time, $60 \mathrm{~min}$ ). Stable column operating conditions (constant active height of the column: distance between upper and lower phase separation limits) were accomplished at a pulsation rate equal to $36 \mathrm{pul} / \mathrm{min}$ and mass ratio of solvent to biodiesel 1.4. Under the specified conditions, the time needed for the column to achieve the stationary condition was experimentally determined by collecting samples of purified biodiesel every $5 \mathrm{~min}$, followed by the measurements of ${ }^{1} \mathrm{H}$ NMR spectra. Obtained results are given in Figure 8. It can be seen that the intensity of the signals characteristic for the hydroxyl group at 2.86 and 3.44 ppm decreased over time. Based on the total FAME content (Figure 9), it was concluded that the stationary conditions were achieved after $15 \mathrm{~min}$. Equation (1) was used to calculate the total FAME content [50].

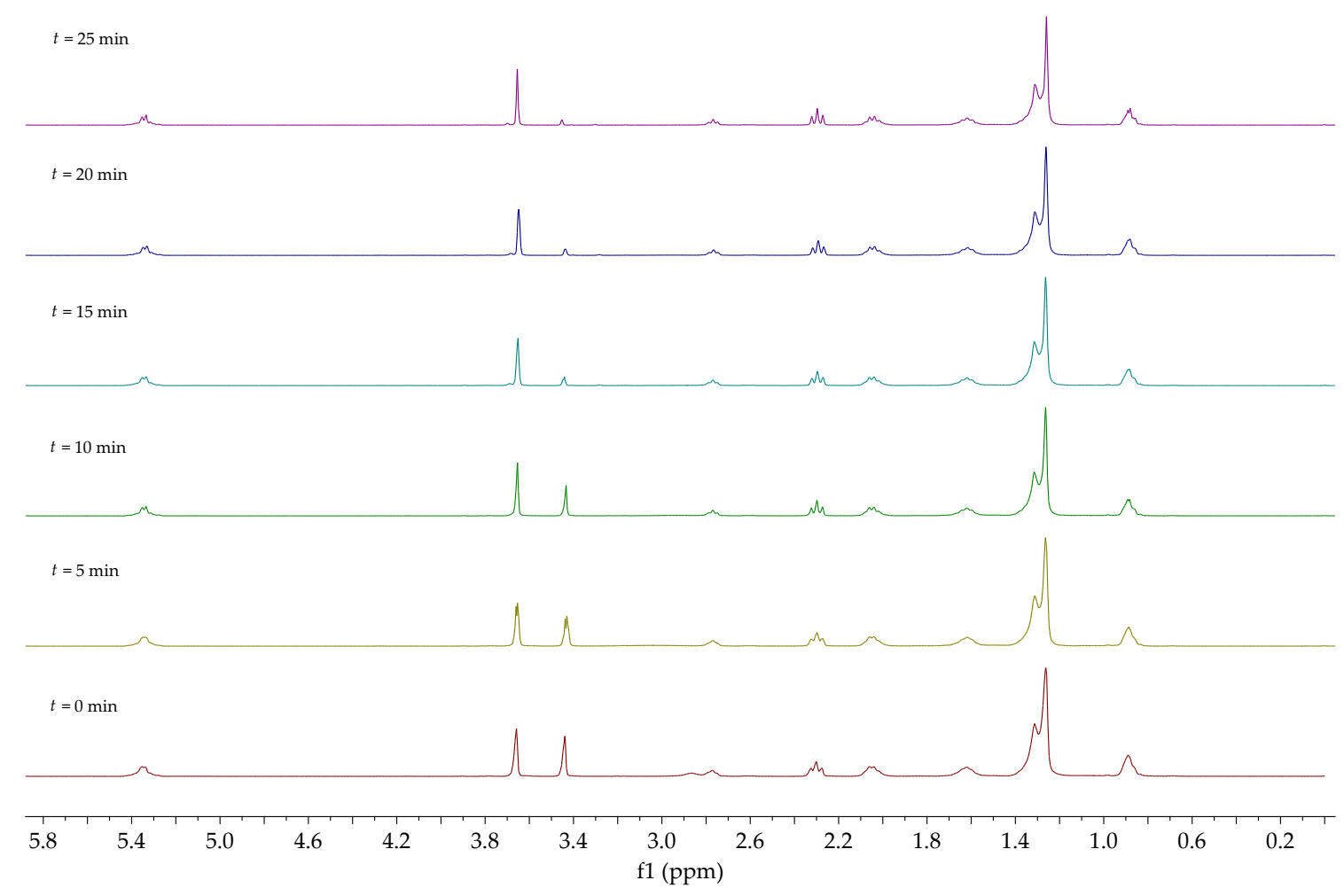

Figure 8. ${ }^{1} \mathrm{H}$ NMR spectra of biodiesel samples collected during column extraction. 


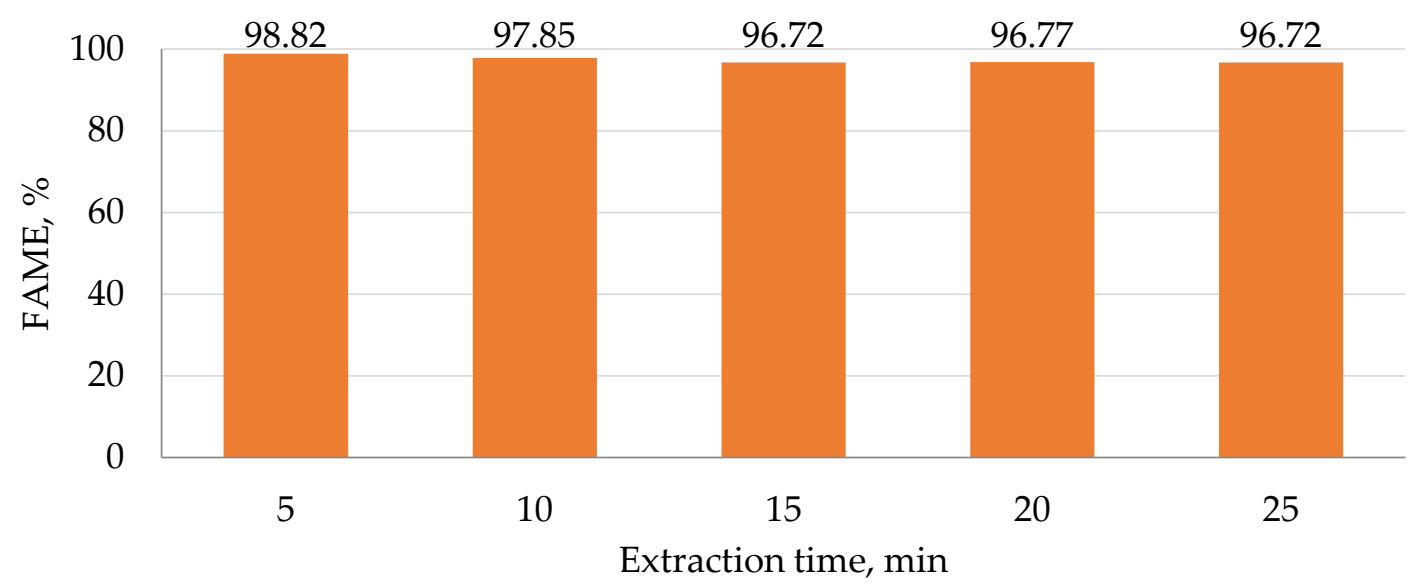

Figure 9. The influence of the extraction time on the FAME content in biodiesel.

The obtained results are presented in Figure 9. It can be seen that the initial FAME content was slightly reduced from 98.82 to $96.72 \%$, which indicates the possible low solubility of FAME in the selected DES. Since FAME content did not decrease below the EN 14214 limit, the solvent can be used for the purification of crude biodiesel. The measured characteristic properties of purified biodiesel are presented in Table 8. The purified biodiesel synthesized from WCGO3 fulfills the standard specification (EN 14214) for biodiesel in terms of density, kinematic viscosity, ester content, TAN, iodide number, and linoleic acid methyl ester as well as glycerol and glyceride content.

Table 8. Specification of biodiesel after column extraction.

\begin{tabular}{ccccc}
\hline Property & Unit & Biodiesel & Standard & Method \\
\hline Density at $15^{\circ} \mathrm{C}$ & $\mathrm{g} / \mathrm{cm}^{3}$ & 0.887 & $0.86-0.90$ & HRN EN ISO 3675 \\
Kinematic viscosity at $40^{\circ} \mathrm{C}$ & $\mathrm{mm}^{2} / \mathrm{s}$ & 4.79 & $3.5-5.0$ & HRN EN ISO 2104 \\
Ester content & $\%(\mathrm{~m} / \mathrm{m})$ & 96.7 & $>96.5$ & HRN EN ISO 23015:1997 \\
TAN & $\mathrm{mg} \mathrm{KOH} / \mathrm{g}$ & 0.44 & $<0.5$ & HRN EN 14104 \\
Iodide number & $\mathrm{g} \mathrm{I} / 100 \mathrm{~g}$ & 85.1 & $<120$ & HRN EN 16300:2012 \\
Linolenic acid methyl ester & $\%(\mathrm{~m} / \mathrm{m})$ & 1 & $<12$ & HRN EN 14103:2011 \\
Monoglyceride content & $\%(\mathrm{~m} / \mathrm{m})$ & 0.69 & $<0.7$ & HRN EN 14105:2011 \\
Diglyceride content & $\%(\mathrm{~m} / \mathrm{m})$ & 0.04 & $<0.2$ & HRN EN 14105:2011 \\
Triglyceride content & $\%(\mathrm{~m} / \mathrm{m})$ & 0.02 & $<0.2$ & HRN EN 14105:2011 \\
Free glycerin & $\%(\mathrm{~m} / \mathrm{m})$ & 0.02 & $<0.02$ & HRN EN 14105:2011 \\
Total glycerin & $\%(\mathrm{~m} / \mathrm{m})$ & 0.21 & $<0.25$ & HRN EN 14105:2011 \\
\hline
\end{tabular}

\section{Conclusions}

A potassium based deep eutectic solvent was successfully used for the extraction of free fatty acids from WCGO and FCGO. The process conditions were mild $\left(25^{\circ} \mathrm{C}\right)$, duration was short $(30 \mathrm{~min})$, and the mass ratio of DES to oil was 0.1 to 1 , which are all beneficial factors for the potential scale-up of the process to the industrial level. Biodiesels were synthesized with two different basic catalysts $(\mathrm{NaOH}$ and $\mathrm{KOH}) . \mathrm{KOH}$ proved slightly more effective and it was chosen for further experiments. Different catalyst:methanol:oil ratios were investigated and the results demonstrated that varying the amounts of catalyst and methanol had almost negligible effects on the final biodiesel quality. The most important factor influencing biodiesel quality was the composition and quality of waste coffee grounds, which led us to conclude that the optimal process conditions have to be determined for each particular type of waste coffee grounds. Choline chloride DES was used for the purification of crude biodiesel in both the batch and continuous experiments. High amounts of free glycerol and glycerides were removed; after the batch experiments, the final content was just slightly above the legal limit, and after continuous purification in a Karr column, the biodiesel content was of excellent quality with glycerol 
and glyceride contents below the EN 14214 limit. Before implementation of the proposed method for the purification of WCGO, the production of biodiesel from WCGO and purification of crude biodiesel in a commercial process, a detailed chemical composition of WCGO, and a study of the solubility of different compounds present in WCGO must be performed.

Author Contributions: Conceptualization, A.S. and A.P.; Methodology, A.S. and A.P.; Formal analysis, A.S., A.P., J.P.V., and L.H.; Investigation, A.P.; Resources, A.S. and A.P.; Data curation, A.S. and A.P.; Writing-original draft preparation, A.S. and A.P.; Writing—review and editing, A.S. and A.P.; Visualization, A.P.; supervision, A.S. All authors have read and agreed to the published version of the manuscript.

Funding: This research received no external funding.

Conflicts of Interest: The authors declare no conflicts of interest.

\section{References}

1. Speer, K.; Kölling-Speer, I. The lipid fraction of the coffee bean. Brazilian J. Plant Physiol. 2006, 18, $201-216$. [CrossRef]

2. Murthy, P.S.; Madhava Naidu, M. Sustainable management of coffee industry by-products and value addition-A review. Resour. Conserv. Recycl. 2012, 66, 45-58. [CrossRef]

3. Kamil, M.; Ramadan, K.M.; Awad, O.I.; Ibrahim, T.K.; Inayat, A.; Ma, X. Environmental impacts of biodiesel production from waste spent coffee grounds and its implementation in a compression ignition engine. Sci. Total Environ. 2019, 675, 13-30. [CrossRef] [PubMed]

4. Coffee Development Report 2019; INTERNATIONAL COFFEE ORGANIZATION: London, UK, 2019; p. 80.

5. Campos-Vega, R.; Loarca-Piña, G.; Vergara-Castañeda, H.A.; Dave Oomah, B. Spent coffee grounds: A review on current research and future prospects. Trends Food Sci. Technol. 2015, 45, 24-36. [CrossRef]

6. Elbl, J.; Plošek, L.; Kintl, A.; Přichystalová, J.; Záhora, J.; Friedel, J.K. The effect of increased doses of compost on leaching of mineral nitrogen from arable land. Polish J. Environ. Stud. 2014, 23, 697-703.

7. Beker, S.A.; Machado, M.E.; Maciel, G.P.S.; Silva, R.; Cataluña, R.; Caramão, E.B.; Bento, F.M. Antimicrobial potential of bio-oil for use in diesel oil B10. J. Braz. Chem. Soc. 2016, 27, 91-98. [CrossRef]

8. Gürü, M.; Koca, A.; Can, Ö.; Çinar, C.; Şahin, F. Biodiesel production from waste chicken fat based sources and evaluation with $\mathrm{Mg}$ based additive in a diesel engine. Renew. Energy 2010, 35, 637-643. [CrossRef]

9. Dufour, J.; Iribarren, D. Life cycle assessment of biodiesel production from free fatty acid-rich wastes. Renew. Energy 2012, 38, 155-162. [CrossRef]

10. Chakraborty, R.; Gupta, A.K.; Chowdhury, R. Conversion of slaughterhouse and poultry farm animal fats and wastes to biodiesel: Parametric sensitivity and fuel quality assessment. Renew. Sustain. Energy Rev. 2014, 29, 120-134. [CrossRef]

11. Banković-Ilić, I.B.; Stojković, I.J.; Stamenković, O.S.; Veljkovic, V.B.; Hung, Y.T. Waste animal fats as feedstocks for biodiesel production. Renew. Sustain. Energy Rev. 2014, 32, 238-254. [CrossRef]

12. Rajak, U.; Nashine, P.; Verma, T.N. Effect of spirulina microalgae biodiesel enriched with diesel fuel on performance and emission characteristics of CI engine. Fuel 2020, 268, 117305. [CrossRef]

13. Ribeiro, A.; Carvalho, J.; Castro, J.; Araújo, J.; Vilarinho, C.; Castro, F. Alternative feedstocks for biodiesel production. Mater. Sci. Forum 2013, 730-732, 623-629. [CrossRef]

14. Goh, B.H.H.; Ong, H.C.; Chong, C.T.; Chen, W.H.; Leong, K.Y.; Tan, S.X.; Lee, X.J. Ultrasonic assisted oil extraction and biodiesel synthesis of Spent Coffee Ground. Fuel 2020, 261, 116-121. [CrossRef]

15. Efthymiopoulos, I.; Hellier, P.; Ladommatos, N.; Kay, A.; Mills-Lamptey, B. Effect of Solvent Extraction Parameters on the Recovery of Oil From Spent Coffee Grounds for Biofuel Production. Waste Biomass Valorizat. 2019, 10, 253-264. [CrossRef] [PubMed]

16. Gómez-De La Cruz, F.J.; Cruz-Peragón, F.; Casanova-Peláez, P.J.; Palomar-Carnicero, J.M. A vital stage in the large-scale production of biofuels from spent coffee grounds: The drying kinetics. Fuel Process. Technol. 2015, 130, 188-196. [CrossRef]

17. Tuntiwiwattanapun, N.; Usapein, P.; Tongcumpou, C. The energy usage and environmental impact assessment of spent coffee grounds biodiesel production by an in-situ transesterification process. Energy Sustain. Dev. 2017, 40, 50-58. [CrossRef] 
18. Tuntiwiwattanapun, N.; Monono, E.; Wiesenborn, D.; Tongcumpou, C. In-situ transesterification process for biodiesel production using spent coffee grounds from the instant coffee industry. Ind. Crops Prod. 2017, 102, 23-31. [CrossRef]

19. Park, J.; Kim, B.; Lee, J.W. In-situ transesterification of wet spent coffee grounds for sustainable biodiesel production. Bioresour. Technol. 2016, 221, 55-60. [CrossRef]

20. Liu, Y.; Tu, Q.; Knothe, G.; Lu, M. Direct transesterification of spent coffee grounds for biodiesel production. Fuel 2017, 199, 157-161. [CrossRef]

21. Nguyen, H.C.; Nguyen, M.L.; Wang, F.M.; Juan, H.Y.; Su, C.H. Biodiesel production by direct transesterification of wet spent coffee grounds using switchable solvent as a catalyst and solvent. Bioresour. Technol. 2020, 296, 122334. [CrossRef]

22. Mueanmas, C.; Nikhom, R.; Kaew-On, J.; Prasertsit, K. Statistical Optimization for Esterification of Waste Coffee Grounds Oil using Response Surface Methodology. In Proceedings of the Energy Procedia, Bangkok, Thailand, 25-26 May 2017; Volume 138, pp. 235-240.

23. Mueanmas, C.; Nikhom, R.; Petchkaew, A.; Iewkittayakorn, J.; Prasertsit, K. Extraction and esterification of waste coffee grounds oil as non-edible feedstock for biodiesel production. Renew. Energy 2019, 133, 1414-1425. [CrossRef]

24. Kondamudi, N.; Mohapatra, S.K.; Misra, M. Spent coffee grounds as a versatile source of green energy. J. Agric. Food Chem. 2008, 56, 11757-11760. [CrossRef] [PubMed]

25. Zhang, Q.; De Oliveira Vigier, K.; Royer, S.; Jérôme, F. Deep eutectic solvents: Syntheses, properties and applications. Chem. Soc. Rev. 2012, 41, 7108-7146. [CrossRef] [PubMed]

26. Yoo, D.E.; Jeong, K.M.; Han, S.Y.; Kim, E.M.; Jin, Y.; Lee, J. Deep eutectic solvent-based valorization of spent coffee grounds. Food Chem. 2018, 255, 357-364. [CrossRef]

27. Krisanti, E.A.; Saputra, K.; Arif, M.M.; Mulia, K. Formulation and characterization of betaine-based deep eutectic solvent for extraction phenolic compound from spent coffee grounds. In Proceedings of the AIP Conference Proceedings, Tangerang, Indonesia, 23-24 October 2019.

28. Procentese, A.; Raganati, F.; Olivieri, G.; Russo, M.E.; Rehmann, L.; Marzocchella, A. Deep Eutectic Solvents pretreatment of agro-industrial food waste. Biotechnol. Biofuels 2018, 11, 37. [CrossRef]

29. Tang, B.; Lee, Y.J.; Park, H.E.; Row, K.H. Pretreatment of Biodiesel by Esterification of Palmitic Acid in Brønsted-Lowry Acid Based Deep Eutectic Solvents. Anal. Lett. 2014, 47, 2443-2450. [CrossRef]

30. Hayyan, A.; Ali Hashim, M.; Mjalli, F.S.; Hayyan, M.; AlNashef, I.M. A novel phosphonium-based deep eutectic catalyst for biodiesel production from industrial low grade crude palm oil. Chem. Eng. Sci. 2013, 92, 81-88. [CrossRef]

31. Hayyan, A.; Hashim, M.A.; Hayyan, M.; Mjalli, F.S.; Alnashef, I.M. A new processing route for cleaner production of biodiesel fuel using a choline chloride based deep eutectic solvent. J. Clean. Prod. 2014, 65, 246-251. [CrossRef]

32. Hayyan, A.; Hashim, M.A.; Hayyan, M.; Mjalli, F.S.; AlNashef, I.M. A novel ammonium based eutectic solvent for the treatment of free fatty acid and synthesis of biodiesel fuel. Ind. Crops Prod. 2013, 46, 392-398. [CrossRef]

33. Zhao, H.; Baker, G.A.; Holmes, S. New eutectic ionic liquids for lipase activation and enzymatic preparation of biodiesel. Org. Biomol. Chem. 2011, 9, 1908-1916. [CrossRef]

34. Shahbaz, K.; Mjalli, F.S.; Hashim, M.A.; Al Nashef, I.M. Using deep eutectic solvents for the removal of glycerol from palm oil-based biodiesel. J. Appl. Sci. 2010, 10, 3349-3354. [CrossRef]

35. Shahbaz, K.; Mjalli, F.S.; Hashim, M.A.; Alnashef, I.M. Eutectic solvents for the removal of residual palm oil-based biodiesel catalyst. Sep. Purif. Technol. 2011, 81, 216-222. [CrossRef]

36. Shahbaz, K.; Mjalli, F.S.; Hashim, M.A.; AlNashef, I.M. Elimination of All Free Glycerol and Reduction of Total Glycerol from Palm Oil-Based Biodiesel Using Non-Glycerol Based Deep Eutectic Solvents. Sep. Sci. Technol. 2013, 48, 1184-1193. [CrossRef]

37. Sander, A.; Antonije Košćak, M.; Kosir, D.; Milosavljević, N.; Parlov Vuković, J.; Magić, L. The influence of animal fat type and purification conditions on biodiesel quality. Renew. Energy 2018, 118, 752-760. [CrossRef]

38. Massey, J.L. Coffee: Production, Consumption and Health Benefits; Nova Science Publishers: Hauppauge, NY, USA, 2016. 
39. Jenkins, R.W.; Stageman, N.E.; Fortune, C.M.; Chuck, C.J. Effect of the type of bean, processing, and geographical location on the biodiesel produced from waste coffee grounds. Energy Fuels 2014, 28, 1166-1174. [CrossRef]

40. Ismail, A.A.; van de Voort, F.R.; Emo, G.; Sedman, J. Rapid quantitative determination of free fatty acids in fats and oils by fourier transform infrared spectroscopy. J. Am. Oil Chem. Soc. 1993, 70, 335-341. [CrossRef]

41. Rabelo, S.N.; Ferraz, V.P.; Oliveira, L.S.; Franca, A.S. FTIR Analysis for Quantification of Fatty Acid Methyl Esters in Biodiesel Produced by Microwave-Assisted Transesterification. Int. J. Environ. Sci. Dev. 2015, 6, 964-969. [CrossRef]

42. Defernez, M.; Wren, E.; Watson, A.D.; Gunning, Y.; Colquhoun, I.J.; Le Gall, G.; Williamson, D.; Kemsley, E.K. Low-field 1H NMR spectroscopy for distinguishing between arabica and robusta ground roast coffees. Food Chem. 2017, 216, 106-113. [CrossRef]

43. Deepayan, P.; Karar, P.K. Utilising FTIR and Gas chromatograph for optimizing lipid extraction for biodiesel production from domestic sewage sludge and food waste. Res. J. Chem. Environ. 2017, 21, $26-36$.

44. Farah, A.; Donangelo, C.M. Phenolic compounds in coffee. Brazilian J. Plant Physiol. 2006, 18, $23-36$. [CrossRef]

45. Franca, A.S.; Oliveira, L.S. Coffee and its by-products as sources of bioactive compounds. In Coffee: Production, Consumption and Health Benefits; Nova Science Publishers: Hauppauge, NY, USA, 2016.

46. Barchan, A.; Bakkali, M.; Arakrak, A.; Pagán, R.; Laglaoui, A. The effects of solvents polarity on the phenolic contents and antioxidant activity of three Mentha species extracts. Int. J. Curr. Microbiol. Appl. Sci. 2014, 3, 399-412.

47. Ruesgas-Ramón, M.; Figueroa-Espinoza, M.C.; Durand, E. Application of Deep Eutectic Solvents (DES) for Phenolic Compounds Extraction: Overview, Challenges, and Opportunities. J. Agric. Food Chem. 2017, 65, 3591-3601. [CrossRef] [PubMed]

48. Alañón, M.E.; Ivanović, M.; Gómez-Caravaca, A.M.; Arráez-Román, D.; Segura-Carretero, A. Choline chloride derivative-based deep eutectic liquids as novel green alternative solvents for extraction of phenolic compounds from olive leaf. Arab. J. Chem. 2020, 13, 1685-1701. [CrossRef]

49. Häkkinen, R.; Abbott, A. Solvation of carbohydrates in five choline chloride-based deep eutectic solvents and the implication for cellulose solubility. Green Chem. 2019, 21, 4673-4682. [CrossRef]

50. Samios, D.; Pedrotti, F.; Nicolau, A.; Reiznautt, Q.B.; Martini, D.D.; Dalcin, F.M. A Transesterification Double Step Process-TDSP for biodiesel preparation from fatty acids triglycerides. Fuel Process. Technol. 2009, 90, 599-605. [CrossRef] 